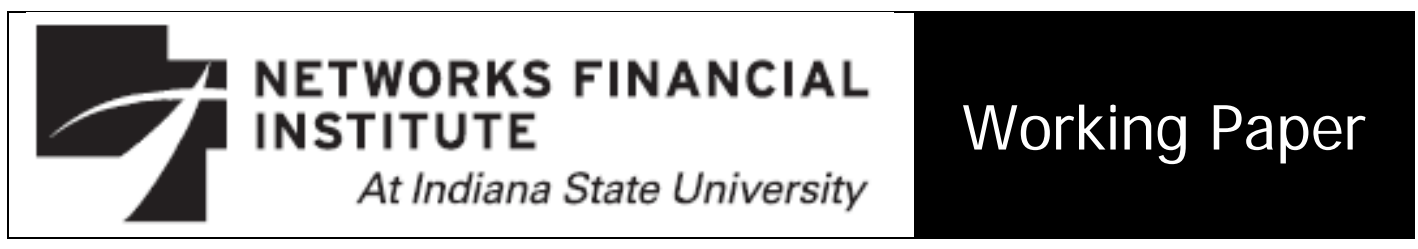

2017-WP-04

October 2017

\title{
Determinants of Bank Capital in Dual Banking Systems
}

\author{
Mohammad Bitar, M. Kabir Hassan, \& William J . \\ Hippler
}

Abstract: We report new evidence on the bank and country-level determinants of Islamic bank capital ratios in 28 countries between 1999 and 2013. Overall, we find that smaller, more profitable, and highly liquid Islamic banks are more highly capitalized. Additionally, improvements in the economic and financial environments and market discipline within a country correspond with higher Islamic bank capitalization. The results shed light on the impact that Sharia'a law restrictions have on Islamic banking capitalization. Our findings are most robust to banks that choose to hold capital well in excess of that required by regulators, consistent with traditional capital structure theory. Our results highlight the role that stable economic and political systems play in improving bank capitalization and reducing financial sector risk. By reducing political instability and corruption, improving legal systems, and encouraging access to capital markets, policymakers may incentivize mangers to make financing decisions that increase the capitalization of the Islamic banking industry in developing countries.

A bout the Authors: Mohammad Bitar holds a PhD degree in Finance from Grenoble Alps University in France. He is a Post-Doctoral fellow at the David O'Brien Center for Sustainable Enterprise. Dr. Bitar teaches masters level courses in banking regulation and economics at the Faculty of Business Administration and Economics of Lebanese University. His current research interests focus on ethical and alternative financial systems, corporate governance, mergers and acquisitions, and corporate social responsibility. $\mathbf{M}$. Kabir Hassan is Professor of Finance in the Department of Economics and Finance in the University of New Orleans. He currently holds two endowed Chairs-Hibernia Professor of Economics and Finance, and Bank One Professor in Business- in the University of New Orleans. Professor Hassan is the winner of the 2016 IDB Prize in Islamic Banking and Finance. Professor Hassan received his M.A. in Economics and Ph.D. in Finance from the University of Nebraska-Lincoln, USA respectively. William J. Hippler, III earned an M.B.A. from Millsaps College and a Ph.D. from the University of New Orleans before joining the faculty at La Verne in 2014. He teaches undergraduate and graduate finance courses and conducts research in the fields of investments and financial markets.

Keyw ords: bank capitalization, Islamic banking, institutional environment, political distress, market discipline, democracy.

$$
\text { J EL classification: G24, G32, K22 }
$$

The views expressed are those of the individual author and do not necessarily reflect official positions of Networks Financial Institute. Please address questions regarding content to the authors. Any errors or omissions are the responsibility of the authors.

NFI working papers and other publications are available on NFI's website (www.networksfinancialinstitute.org). Click "Publications" 


\title{
Determinants of Bank Capital in Dual Banking Systems
}

\author{
Mohammad Bitar \\ David O'Brien Centre for Sustainable Enterprise \\ John Molson School of Business \\ Concordia University \\ 1455 Blvd. de Maisonneuve West \\ Montréal, QC H3G 1M8, Canada \\ E-mail: mohammad.bitar@concordia.ca \\ M. Kabir Hassan \\ Professor of Finance and \\ Hibernia Professor of Economics and Finance and \\ Bank One Professor of Business \\ Department of Economics and Finance \\ University of New Orleans \\ New Orleans, LA 70148, USA \\ Phone: 504-280-6163 \\ Email: mhassan@uno.edu \\ William J. Hippler \\ Assistant Professor of Finance \\ College of Business and Public Management \\ University of La Verne \\ 1950 Third St. \\ La Verne, CA 91750 \\ Phone: 909-448-1587 \\ Email: whippler@laverne.edu
}

October 26, 2017 


\title{
Determinants of Bank Capital in Dual Banking Systems
}

\begin{abstract}
We report new evidence on the bank and country-level determinants of Islamic bank capital ratios in 28 countries between 1999 and 2013. Overall, we find that smaller, more profitable, and highly liquid Islamic banks are more highly capitalized. Additionally, improvements in the economic and financial environments and market discipline within a country correspond with higher Islamic bank capitalization. The results shed light on the impact that Sharia'a law restrictions have on Islamic banking capitalization. Our findings are most robust to banks that choose to hold capital well in excess of that required by regulators, consistent with traditional capital structure theory. Our results highlight the role that stable economic and political systems play in improving bank capitalization and reducing financial sector risk. By reducing political instability and corruption, improving legal systems, and encouraging access to capital markets, policymakers may incentivize mangers to make financing decisions that increase the capitalization of the Islamic banking industry in developing countries.
\end{abstract}

JEL classification: G24, G32, K22

Keywords: bank capitalization, Islamic banking, institutional environment, political distress, market discipline, democracy. 


\section{Introduction}

The recent global financial crisis brings to light the important role that the institutional environment of a country can play in financial sector stability. Accordingly, regulatory bodies, such as the Basel Committee on Banking and Supervision (BCBS) and other policymakers desire to enact appropriate bank capital requirements, among other measures, to control banking sector risk and governance. Therefore, understanding the determinants of firm capital structures becomes an important empirical issue. Previous research outlines the impact that firm-level and institutional characteristics have on the capital structure decisions of real sector firms and conventional banks; however, the determinants of the capital structure decisions of financial firms operating in developing countries and Islamic banks, in particular, is not well established. Therefore, as developing countries become more integrated with the global financial system, understanding the factors that drive the capital structure decisions of banks in developing countries and their impact on the global markets becomes increasingly important. In addition, Islamic banks face unique capital structure restrictions due to Islamic law, and many Islamic banks operate in developing countries. In this study, we provide new evidence on the capital structure decisions of Islamic banks by estimating the impact of bank and country-level characteristics on the capitalization of Islamic banks. We provide important evidence on the effect that a country's institutional environment has on bank capitalization decisions, and the results have important implications for financial sector stability and governance, particularly in developing countries with an Islamic banking presence.

As one of the fastest growing developing financial systems, Islamic banking is expanding rapidly in both Muslim and non-Muslim countries. Islamic bank assets are expected to reach $\$ 6.5$ trillion by 2020 (Mollah et al., 2016), with an annual growth rate of 19.7\% from 2013 to 2018 (Ernst and Young, 2013). Islamic banks are financial intermediaries that are compliant with Sharia'a law (Gheeraert, 2014). Thus, they allocate and invest resources under the guidance of Sharia'a principles without any use of interest in order to achieve “ [...] a fair system of social justice and equality while fulfilling the financial needs of people and maintaining high standards of ethics, transparency and a sense of responsibility". ${ }^{1}$ The word "fair" refers to the principle of risk sharing between Islamic banks, investors, and depositors (i.e., all transactions must reflect a symmetrical risk and return

\footnotetext{
${ }^{1}$ The definition of an Islamic bank according to The Dubai Islamic bank, the oldest Islamic commercial bank.
} 
distribution among all parties). The term "social justice and equality" reflects the fact that Islamic banks face constraints on their profit-seeking behavior, the structuring of their financial products (i.e., prohibition of products that contain uncertainty or information asymmetries), and the relationship with stakeholders (i.e., no exploitation of other parties). These characteristics make Islamic bank investment and financing decisions more conservative. (Abedifar et al. 2013). The transparency concept mentioned in the definition refers to the materiality and the traceability of Islamic bank transactions (i.e., Islamic banking products must be backed by tangible assets in the real economy). Finally, the terms "high standards of ethics" and "sense of responsibility" reflect the principle of prohibiting the financing of sinful and non-ethical activities defined by Islamic law, such as dealing in the gambling, alcohol, or tobacco industries.

Like conventional financial intermediaries, Islamic banks operate in a highly regulated industry. However, due to their special characteristics, i.e., the concept of profit and loss sharing on both the asset (entrepreneur/borrowers) and liability (depositors/investors) sides, their capital ratios must not only adhere to the regulatory guidelines of the Basel Committee on Banking and Supervision (BCBS), but also to specific capital guidelines proposed by the Islamic Financial Services Board (IFSB) and the Accounting and Auditing Organisation for Islamic Financial Institutions (AAOIFI). Therefore, regulators are concerned with how to treat Sharia'a compliant Islamic banks. While some regulators try to fit Islamic banks into the existing regulatory framework, others try to create a separate regulatory framework that deals specifically with Sharia'a compliant finance. In order to understand which framework most appropriately fits Islamic banking institutions, we need to examine the most influential determinants of Islamic bank capital ratios. Accordingly, we specifically focus on Islamic bank capital decisions.

In addition to the key role that Islamic banks play in promoting financial inclusion and economic growth in Muslim countries (Demirgüç-Kunt et al., 2013; Imam and Kpodar, 2015), recent studies show that Islamic banks are becoming systemically important (Song and Oosthuizem, 2014). Islamic banks are also expected to promote social welfare by encouraging ethical values and financial behavior (Gheeraert, 2014). Thus, it is of interest to examine whether Islamic bank capital strategies are determined by the same factors observed in the conventional banking literature. Moreover, several Islamic countries are moving away from centrally-based economies toward more open economies and are, thus, connecting their financial markets with the global financial system. For example, Islamic 
financial institutions may now benefit from the broader financial markets by observing several Islamic indexes that are Sharia'a compliant, such as the Hong Kong Islamic Index (HKII), the MSCI Islamic index, and the Dow Jones Islamic Market Index (DJIM). Such development should, in turn, drive Islamic banks to update their contracts to become more pragmatic in terms of investment and funding strategies. Finally, Islamic banks located in Islamic countries are often constrained by multiple banking regulatory standards, and they operate in an environment of relatively weak financial reforms (especially in the MENA region), compared to banks in industrialized countries (Belkhir et al. 2016; Bitar et al. 2016). This is likely to affect the determinants of their capital ratios and, thereby, their optimal financing decisions.

The corporate finance literature offers an extensive body of research on the determinants of firm capital ratios (Frank and Goyal, 2009; Fan et al. 2012, Öztekin and Flannery, 2012; Cho et al. 2014; Öztekin, 2015, Belkhir et al. 2016). In conventional banking, however, the literature often concentrates on whether banks share the same capital determinants as other firms. For example, Gropp and Heider (2010) provide evidence that most determinants of bank capital ratios are identical to those found in other corporate finance studies. Octavia and Brown (2010) reach the same conclusion, but also find that macroeconomic factors play a significant role in determining bank capital structure in developing countries. Recently, Anginer et al. (2016) examine the corporate governance determinants of bank capital structure and show that corporate governance is also an important determinant of bank capital decisions. Finally, Schepens (2016) concludes that reducing dependence on the tax shield can be a very useful tool for regulators in encouraging banks to rely more on equity funding.

In the context of Islamic banks, prior studies focus substantially on the risk, profitability, efficiency, and governance of Islamic banks, compared to conventional banks (e.g. Čihák and Hesse, 2010; Beck et al. 2013; Abedifar et al., 2013; Johnes et al., 2014; Mollah and Zaman, 2015; Mollah et al. 2016). However, the literature on the determinants of Islamic bank capital ratios does not offer any empirical evidence on whether Islamic banks share common determinants with their conventional counterparts and the broader corporate finance literature.

In this paper, we extend the literature to the Islamic banking sector in the Middle East and North Africa (MENA) and South East Asian (SEA) regions in order to identify the determinants of Islamic bank capital ratios and whether the institutional environment, specifically economic and financial 
system development, affects Islamic bank capital decisions, and, if so, how. To empirically answer these questions we select an initial sample of 149 Islamic banks from 33 countries located across both regions. The sample covers the period from 1999 to 2013. We apply traditional corporate finance theories and testing methodologies from the current literature to investigate the most relevant bank and country level determinants of Islamic bank capital ratios (e.g. size, profitability, liquidity, tangibility, and risk).

Our results show that smaller, more profitable, and more liquid Islamic banks that operate in countries with better institutional environments and market discipline have higher capital ratios, consistent with the idea that compliance with Sharia'a law requires holding higher liquidity buffers, especially for small Islamic banks that tend to utilize retained earnings to increase their capital ratios. Our results persist for Islamic banks that hold capital well in excess of regulatory minimums, which is expected, since well capitalized banks are relatively free to choose the capital structures that managers perceive to be most optimal. On the other hand, our results are weakest for banks that hold the minimum required capital. So, we are less able to predict the capital structures of these banks, because they face regulatory and, perhaps, liquidity constraints. Using a first difference estimation technique, we also show that the changes in financial and institutional characteristics are important determinants of changes in Islamic bank capital structure decisions. Moreover, we find that the determinants of Islamic bank capital often change across periods of financial and political distress; however, the impact of bank size and institutional development remain generally consistent across regimes. Most importantly, our results show that measures associated with economic and financial system development, such as low corruption, currency stability, rule of law, and market openness are consistently associated with higher capital ratios across specifications. Finally, our results are consistent when using an IV approach to control for endogeneity and alternative estimation techniques and standard errors.

Our results contribute to the literatures on Islamic finance, developing markets, and the broader corporate finance capital structure literature in several important ways. First, we add to the literature on Islamic finance as it relates to the broader corporate finance capital structure literature. Using common measures, such as size, profitability, risk, asset tangibility, and liquidity, we empirically investigate the determinants of Islamic bank capital and find results similar to the broader corporate finance literature, which implies that standard capital structure theories and empirical results can be 
applied in the case of Islamic banks (Gropp and Heider, 2010; Cho et al., 2014; Belkhir et al., 2016; Schepens, 2016). Secondly, we extend the literature on developing markets as it relates to the broader corporate finance capital structure literature. We examine the effect of macroeconomic factors and the institutional environment on the capital structure decisions of Islamic banks and find that improvements in the institutional environment, such as the reduction of corruption and improvements in capital market access, political and financial stability, and rule of law, result in higher bank capitalization, which has significant policy implications for understanding financial sector risk in the context of developing countries.

The remainder of the paper is organized as follows. Section 2 briefly reviews the related theoretical framework and discusses the predicted bank and country-level effects on Islamic bank capital ratios. Section 3 describes our sample, variables, and empirical model. Section 4 presents the empirical findings. Section 5 reports sensitivity and additional analyses, and the last section concludes.

\section{Related literature and hypotheses}

2.1. Review of capital structure theory and Islamic banks

The two most relevant capital structure theories in an Islamic banking context are the static/dynamic trade-off theory ${ }^{2}$ (Kraus and Litzenberger, 1973) and the pecking order theory (Myers, 1984; Myers and Majluf, 1984).

The trade-off theory states that the optimal capital structure of a bank results from a trade-off between the costs and benefits of debt and equity financing. Accordingly, banks tend to use debt, rather than equity, to maximize their value (Belkhir et al. 2016). They use debt to benefit from the taxshield of interest deductibility. However, since banks have historically had a high share of leverage, compared to the rest of the economy, the tax shield may have a cost, because leverage is directly associated with higher financial distress costs. These costs can be categorized into direct costs (e.g. legal fees related to bankruptcy) and indirect cost (e.g. loss of customers, employees, reputation, business opportunities). Frank and Goyal (2009) argue that the trade-off between these benefits and

\footnotetext{
${ }^{2}$ The main difference between the static and dynamic trade-off theories is that the static theory fixes a target leverage ratio, while the dynamic theory is concerned with the adjustment speed of capital decisions. The latter argues that overleveraged banks tend to adjust their leverage position faster when macroeconomic conditions are in their favor.
} 
costs can be distinguished in several ways. One such example is the "tax-bankruptcy trade-off" hypothesis, where a firm can balance the tax-shield benefit of debt against the increased cost of bankruptcy. Another example is the “agency” hypothesis, where a high dependency on leverage can discipline managers and mitigate agency problems, since debt must be repaid in order to avoid bankruptcy. In the case of Islamic banks, on the asset side, Sharia'a law requires financing activities to be backed by tangible assets, thus creating a safety net that helps reduce their risk exposure. In addition, Islamic banks have a higher share of tangible assets, compared to their conventional counterparts, which reduces the bankruptcy costs for liability claimholders. Furthermore, on the liability side, Sharia'a law imposes constraints on dealing and using debt instruments that correspond to Tier2 capital in Islamic bank capital adequacy ratios. Therefore, Islamic banks tend to have higher Tier1 capital, compared to conventional counterparts. Moreover, their Tier1 capital is almost equal to the capital adequacy ratio, because Tier2 capital is rarely used. Therefore, the bankruptcy costs for Islamic banks is expected to be lower than that of conventional intermediation, because their business model favors the use of higher quality capital over debt when external funding is required.

In contrast to trade-off theory, the pecking order theory of Myers (1984) and Myers and Majluf (1984) does not provide for any optimal capital structure. Due to information asymmetry between managers, shareholders, and outside investors, this theory suggests a predefined financial hierarchy of bank financing choices. Banks prioritize retained earnings as the best source of funds. If internal funding is not available, debt or convertible bonds will be used. Equity is considered the last resort, because managers often believe that the issuance of equity will be underpriced by the market (Belkhir et al., 2016). However, under Sharia'a law, Islamic banks are required to be fully transparent in their transactions. For instance, Sharia'a law prohibits Gharar and, thus, information asymmetry between Islamic banks and stakeholders is not permitted. In addition, Maysir, or excessive risk-taking, is not allowed, so many conventional banking practices, such as market speculation, securitization, and the use of other financial derivatives, are prohibited. Therefore, evaluating Islamic bank risk exposure should be less complex for external investors. Another principle for Islamic banks is the tangibility and traceability of assets. Therefore, all financial transactions by Islamic banks (e.g. Murabaha, Ijara, Salam, and Istisina'a) must be backed by tangible assets. In conventional banks, a borrower can immorally and without notifying the bank - use the borrowed funds for activities other than that which was initially agreed. These activities often comprise higher risk engagement and, consequently, increases moral hazard problems. In Islamic banks, instead of providing a loan to a borrower to 
finance the purchase of an asset, the Islamic bank will buy or construct the asset in question and sell or rent it to the borrower. This principle allows the Islamic bank to have a clearer view of the allocation of its resources. Moreover, Sharia'a law requires that these resources be invested in socially responsible activities that benefit community growth and development. Another important feature of Islamic banks is the profit and loss sharing contracts (e.g. Musharaka and Mudaraba) that are based on participatory finance and can also reduce moral hazard problems. Under the Musharaka contract, Islamic banks are allowed to control the activities of the entrepreneur, while under the Mudaraba contract, the Islamic bank encourages the entrepreneur to provide the needed effort to manage the project, since its repayment depends upon the experience and knowledge of the entrepreneur. Therefore, under Sharia'a law, Islamic banks will be less exposed to information asymmetry and the disadvantages related to the evaluation of and access to investors' private information. As a result, the transparency, asset tangibility, and profit/loss sharing features of Islamic banks should reduce their risk exposure, information asymmetry, and use of debt, which will ultimately lead the bank to favor internal funds as a first choice in funding, followed by raising quality external capital.

\subsection{Bank-level determinants of Islamic bank capital ratios}

In this section, we provide a detailed description of the different bank-level determinants of capital ratios that are commonly used in the banking and corporate finance literatures (Gropp and Heider, 2010; Octavia and Brown, 2010; Cho et al., 2014; Belkhir et al., 2016; Schepens, 2016). We also discuss our expectation regarding their impact on Islamic bank capital ratios, given the institutional and contracting environments.

\subsubsection{Size}

Both the corporate finance and conventional banking literature agree that large firms and banks are more experienced, more reputable, and have a more diversified portfolio of activities and investments. They also have less volatile earnings, better access to capital markets, and can raise debt at lower costs. Therefore, larger firms and banks face lower default risk and are expected to have lower capital ratios. Thus, trade-off theory predicts a negative effect of bank size on bank capital. According to Belkhir et al. (2016), bank size can be used as a proxy for information asymmetry between inside and outside investors. Fama and Jensen (1983) also argue that larger firms are less 
likely to suffer from information asymmetry, because they are less subject to adverse selection and are expected to have easier access to both debt and equity markets. Islamic banks, however, suffer from several weaknesses, compared to conventional counterparts. Islamic banks are less experienced, they cannot utilize many common debt instruments, because debt is forbidden under Sharia'a law, and they often operate in an underdeveloped financial market (e.g. a weak institutional and contracting environment). In addition, many of an Islamic bank's target customers prefer not to deal with banking institutions at all, including Islamic banks, and instead choose to keep their wealth outside the financial system. Accordingly, the Islamic banking literature points to larger Islamic banks as having advantages in terms of experience, reputation, risk management, economies of scale, as well as information accessibility (Beck et al. 2013, Abedifar et al. 2013). In our analysis, we follow the standard corporate finance and conventional bank literature and use the natural logarithm of total assets as a measure of bank size, and we expect a negative association between size and Islamic bank capital ratios.

\subsubsection{Profitability}

There is no general consensus on the effect of profitability on firm and bank capital ratios. According to static trade-off theory, more profitable firms/banks are likely to have higher leverage ratios. Frank and Goyal (2009) argue that profitable firms face lower bankruptcy costs and can also benefit from the tax shield to take on more debt. However, the authors explain that, in a dynamic framework, profits can have a negative effect on leverage due to various frictions. According to pecking order theory, firms and banks prefer internal funds over external funds and, thus, their need for the latter is lower. So, in contrast to static trade-off theory, all things being equal, leverage is expected to be lower for highly profitable firms and banks. Islamic banks also prefer internal funds to finance their investments. Compared to conventional banks, Islamic banks are less capable of raising debt, because of the constraints imposed by Islamic law on the usage of debt instruments. Therefore, Islamic banks are left with two alternatives. The first is to rely on retained earnings, and the second is to raise equity, which could weaken shareholder control over the bank. Belkhir et al. (2016) explain that, in a pecking order context, managers are less motivated to raise equity, because it will be underpriced by the market due to information asymmetry. Moreover, raising debt or equity is also related to the level of financial and economic development in a country. In most Islamic countries, the financial environment is still not well developed, thus these markets are more prone to information 
asymmetry and transaction costs, which makes raising both debt and equity more expensive. In our empirical tests, we use net income to total assets as a measure of Islamic bank profitability and expect a positive impact of profitability on Islamic bank capital ratios.

\subsubsection{Liquidity}

We refer to the banking literature and examine the effect of liquidity on bank capital. Horváth et al. (2013) propose a financial fragility hypothesis under which an inverse relationship between equity capital and liquidity is expected. They argue that, under the trade-off hypothesis, regulatory constraints on capital will severely harm the liquidity position of a bank. Furthermore, banks with more liquid assets face lower bankruptcy costs and are more capable of raising debt, which could negatively affect their capital position. In contrast, pecking order theory suggests that having more liquid assets implies less information asymmetry and, therefore, a better capacity to raise equity (Belkhir et al., 2016). Berger and Bouwman (2012) report similar findings and refer to the risk absorption hypothesis, under which highly capitalized banks generate more liquidity. In the case of Islamic banks, liquidity is considered a major challenge facing the industry. Islamic banks have constraints on accessing liquidity; they cannot use debt instruments and financial derivatives. Islamic banks also suffer from a weak interbank money market, lack of expertise, and inconsistent regulatory standards. As a result, they prefer to hold higher liquidity buffers than conventional banks, which could serve as protection against liquidity risk. Whether more liquidity leads to more or less Islamic bank capital is an empirical question, which we leave to empirical estimation. Due to data availability, we follow the Islamic banking literature and use the ratio of liquid assets to deposits and short term funding to measure Islamic bank liquidity.

\subsubsection{Asset Tangibility}

The availability of fixed assets, such as property, plant, and equipment means that firms and banks can raise more debt secured by those assets. Therefore, banks with more available tangible assets are expected to have lower bankruptcy costs and higher leverage ratios. Under pecking order theory, however, firms and banks with more available tangible assets are less sensitive to information asymmetry. This implies that the cost of issuing equity is expected to be lower than the cost of debt. Therefore, the presence of tangible assets is expected to be positively associated with capital ratios. Due to Sharia'a obligations, Islamic banking transactions should be backed by assets in the real 
economy. However, most Islamic banks operate in underdeveloped countries. For example, Belkhir et al. (2016) reports that, in the MENA region, bankruptcy laws and property rights are weak. They also explain that poor collateral regimes do not enable firms and lenders to rely on intangible assets.

Because of their strong reliance on tangible assets, we expect a positive relationship between tangible assets and Islamic bank capital ratios. Tangible assets can create a security mechanism that can benefit Islamic banks during period of financial stress, although a higher dependency on real estate can also negatively affect Islamic banks if financial distress reaches the real economy (Bitar et al., 2016). However, Pappas et al. (2012) suggest that the involvement of Islamic banks in major government infrastructure projects offers safer income and higher ROA than conventional banks. Olson and Zoubi (2008) argue that the reliance on investment deposits, rather than equity, is the reason for higher Islamic bank ROE. Accordingly, we use the ratio of fixed assets to total assets as a proxy for tangibility when examining the relationship between asset tangibility and Islamic bank capital.

\subsubsection{Risk}

Frank and Goyal (2009) explain that riskier firms with more volatile cash flows are expected to face higher costs of financial distress. Accordingly, stakeholders are less willing to invest in the company and this will result in lower debt under trade-off theory (Belkhir et al., 2016). However, firms with more volatile cash flows can also exhibit adverse selection problems. If so, the pecking order theory predicts a positive effect of risk on firm leverage. The conventional banking literature mostly reports a positive relation between risk and bank capital ratios. Gropp and Heider (2010) argue that, when regulation constitutes the main reason for a departure from the Modigliani and Miller (1958) paradigm, then regulatory authorities can explicitly intervene and force riskier banks to hold more equity capital. Their findings show a positive association between risk and capital, consistent with other studies in the banking literature, such as Octavia and Brown (2010). Due to the complexity of their facilities and contracts, Islamic banks could face moral hazard problems, especially in the face of market imperfections and information asymmetries (Abedifar et al. 2013; Abdul-Karim et al., 2014). Islamic banks have less experienced risk management and are more prone to Sharia'a compliance risk, which can harm their reputation and investor confidence. The effect of bank risk on bank capital is an empirical question, which we leave to the empirical estimations. Accordingly, we follow the Islamic banking literature and use the ratio of net loans to assets to proxy for bank risk. 


\subsection{Country-level determinants of Islamic bank capital ratios}

To capture the role of economic, financial, and institutional development in each country and their effect on Islamic bank capital ratios, we use two sets of country-level control variables: 1) traditional macroeconomic determinants (i.e. GDP growth, inflation rate, and oil, mineral, and gas rents, all scaled by GDP); and 2) institutional development determinants (i.e. rule of law, government intervention, regulatory efficiency, market openness, and the overall index of economic and financial development). Because the financial and institutional environment is a large and complex concept, we argue that, although the components of the economic and financial development index cannot capture all the needed elements, we expect that such an indicator can play the needed role in capturing some of the critical dimensions of financial and institutional development. ${ }^{3}$

\subsubsection{Macroeconomic determinants}

We use five measures to control for potential differences in economic development at the country level. We first include the GDP growth rate and expect that raising equity is more favorable in periods of economic boom and expansion. This is because, in such period, stock prices are higher, expected bankruptcy costs are lower, and taxable income is higher. Accordingly, Islamic bank profits will increase and be held by banks as retained earnings in their capital buffers. Second, we use the inflation rate and expect a positive association with Islamic bank equity. According to the backward looking hypothesis, firm managers tend to raise more debt when they feel that interest rates are particularly low (Barry et al., 2008). Firms, banks, and individuals will borrow and invest more, leading to rapid growth and higher inflation rates. Conversely, when inflation rates are high, Central Banks often intervene and increase interest rates, forcing borrowers to borrow less, which decreases leverage and favors the use internal funds and raising equity. Finally, because many countries in our sample are rich in natural resources, we use three complementary measures, namely, oil rent to GDP, gas rent to GDP, and mineral rent to GDP, ${ }^{4}$ and expect a positive association with Islamic bank capital ratios.

\footnotetext{
${ }^{3}$ The robustness section of the paper also uses another indicator of economic and financial development, which is the economic world freedom index collected from the Fraser institute website of the Economic Freedom Network.

${ }^{4}$ Oil, gas, and minerals rents are the difference between the value of oil, gas, and minerals production at world prices and total costs of production.
} 


\subsubsection{Economic and financial development determinants}

Macroeconomic variables do not cover the institutional environment. So, in this section, we provide insights on the role that the institutional environment might be play in affecting Islamic bank capital ratios. We focus on the economic and financial development index and its different components. Specifically, we use rule of law to measure the capacity of a country's government and legal system to recognize and ensure the protection of property and contract rights. We also control for the level of government intervention in the economy using an indicator of limited government, which measures fiscal freedom and government spending. Furthermore, in measuring regulatory efficiency, we control for three sub-measures: business freedom; labor freedom; and monetary freedom. Finally, we use an index of market openness to control for freedom of trade, freedom of investments, and financial freedom. These four measures constitute the economic and financial development index. The corporate finance and conventional banking literatures show different findings for the effect of the institutional environment on capital ratios. Some authors argue that firms and banks tend to favor debt over equity in countries where the institutional environment is well respected, while others find that firms and banks will prefer raising equity over debt. ${ }^{5}$ These results are often explained by referring to the level of information asymmetry in a country. For instance, Belkhir et al. (2016) find that, when institutions and individuals abide by the law, investors have more confidence in the system and are likely to accept extending credit to firms at better terms (Hanousek and Shamshur, 2011). In contrast, Antoniou et al. (2008) and Gungoraydinoglu and Öztekin (2011) suggest that strict enforcement of law and contracts leads to higher bankruptcy costs and lower leverage ratios. Although the Islamic banking system is bound by Sharia'a law, it operates in an environment that can be affected by weaknesses in the rule of law, governmental intervention, regulatory efficiency, and market openness. Belkhir et al. (2016) describe the institutional environment in the MENA region as weak and underdeveloped, compared to other developing countries. Therefore, the impact of the overall economic and financial development index and its components on Islamic bank capital ratios is an empirical question, which we leave to the empirical model. The overall index and its components range from 0 to 100, with higher values indicating a strong institutional environment. Table 1 summarizes the predicted effects of the different explanatory variables on capital ratios for firms, conventional banks, and Islamic banks.

\footnotetext{
${ }^{5}$ For more details please refer to Antoniou et al. (2008), Gungoraydinoglu and Öztekin (2011), Jõeveer (2013), Belkhir et al. (2016), and Schepens (2016).
} 
[Insert Table 1 here]

\section{Data and Methodology}

\subsection{Sample construction}

We use Bankscope as the primary source of data for this study (Abedifar et al., 2013; Anginer and Demirgüç-Kunt, 2014; Mollah and Zaman, 2015). We also utilize a Bloomberg database to sample market-based financial indicators. For each bank, we sample annual data from 1999 to 2013. Our initial sample includes more than 149 Islamic banks from 33 countries. Macroeconomic data, such as inflation and GDP growth rates, are obtained from the World Bank’s World Development Indicators, whereas financial development and institutional variables are obtained from various sources, such as the Heritage Foundation, The Fraser Institute, and the CIA's World Fact Book. We exclude countries, such as Brunei, the Cayman Islands, Gambia, Palestine, and Philippines, because they have no available data for the economic freedom index. We also exclude Islamic banks with negative capital ratios. Our final sample consists of more than 100 Islamic banks, operating in 28 countries. All variables are winsorized at the $1 \%$ and $99 \%$ levels to mitigate the effect of outliers.

\subsection{Capital Ratios and empirical model}

We follow Demirgüç-Kunt et al. (2013) and Anginer and Demirgüç-Kunt (2014) and use two definitions of bank capitalization ratio. The first measure is bank common equity, divided by total assets (common equity/ta). Common equity includes common shares, retained earnings, reserves for general banking risks, and statutory reserves. The second measure is Tier 1 capital, divided by riskweighted assets and off-balance sheet exposures (Tier 1 capital/rwa). Tier 1 capital is the sum of shareholder funds and perpetual, noncumulative preference shares. This ratio must be at least 6\% under the Basel III rules. We alternate between risk-weighted assets (regulated capital) and total assets (unregulated capital) to avoid any errors related to the calculation of risk-weighted assets (Cathcart et al. 2015; Dermine, 2015; Bitar et al. 2016). For our regression analysis, we employ a random-effect, Generalized Least Squares (GLS) methodology to allow a more robust investigation of the impact of the determinants of Islamic banks capital ratios. Eq. (1) represents our base regression model: 


$$
\begin{aligned}
\text { CAP_Islamic }_{\mathrm{ijt}} & =\alpha+\beta_{1} \times \text { Bank_Trad }_{\mathrm{ijt}-1}+\beta_{1} \times \text { Institutional_det }_{\mathrm{jt}-1}+\beta_{3} \times \text { Macro_eco }_{\mathrm{jt}-1} \\
& +\sum_{\mathrm{T}=1}^{\mathrm{T}} \beta_{3} \times \mathrm{YFE}_{\mathrm{t}}+\varepsilon_{\mathrm{it}},(1)
\end{aligned}
$$

where CAP_Islamic ${ }_{\mathrm{ijt}}$ is the bank's capitalization ratio, Bank_Trad $\mathrm{ijt-1}_{\mathrm{i}}$ includes the bank determinants of capital structure, suggested by the traditional banking and corporate finance literature, i.e. size, profitability, liquidity, asset tangibility, and risk. Institutional_det $\mathrm{j}_{\mathrm{jt-1}}$ is measured by the economic freedom index, which controls for rule of law, government size, regulatory efficiency, and market openness. Macro_eco $\mathrm{jt-1}_{\mathrm{j}}$ controls for differences between country economies and investigates the impact of macroeconomic factors and natural resources on Islamic bank capital ratios. $\mathrm{YFE}_{t}$ is a year fixed effect, and $\varepsilon_{i t}$ is a white-noise error term, assumed to be normally distributed with zero mean and constant variance, $\varepsilon_{\mathrm{it}} \sim$ iid $N\left(0, \sigma^{2}\right)$. All independent variables are lagged one year, because they may take more than one year to impact banking capital. We follow Beck et al. (2013) and Anginer and Demirgüç-Kunt (2014) and cluster at the bank level, instead of the country level, because some countries have a larger number of observations than others. Additionally, we only sample twenty-eight countries. Therefore, clustering at the country level may create biased results.

\section{Empirical findings}

\subsection{Descriptive statistics}

Table 2, Panel A presents summary statistics for the capital ratios, economic development indexes, and bank and country-level financial characteristics for the 28 countries included in our sample. In general, they suggest that there is large cross-country variation in Islamic bank capital ratios. For instance, the Tier 1 capital ratio ranges from a minimum of $9.29 \%$ in Bangladesh to a maximum of $75.18 \%$ in Singapore. Using the traditional common equity ratio, Bangladesh continues to be where Islamic banks are the least capitalized (mean of 6.27\%), and Singapore continues to be the country with the most capitalized Islamic banks (mean of 74.28\%). In Table 2, Panel B, we report that the number of observations varies dramatically between risk-based and non-risk-based capital measures. Tier 1 capital to risk-weighted assets has 739 observations, while common equity to assets has 1,326 observations. The number of missing observations is explained by the fact that most countries started reporting regulatory capital information in 2006, and some banks prefer not to provide information about their capital adequacy ratios and, instead, provide information about their 
traditional capital ratios. Banks in these countries may still be working under the Basel I accord, or prefer not to disclose information about their risk weighting.

\section{[Insert Table 2 here]}

The economic and financial development indexes also vary across countries. Excluding the United Kingdom and Singapore (the two most developed countries in our sample), Bahrain tends to rank towards the top of the economic index $(\mathrm{I})^{6}$, with a mean value of $74.63 \%$, whereas Iraq, Bosnia, and Bangladesh rank towards the bottom, with mean values of 16.8\%, 48.53\%, and 50\%, respectively. Comparing capital ratios with the economic index (I), it is clear that economically developed countries, such as Bahrain, tend to have higher capital ratios.

\section{[Insert Figure 1.A and 1.B here]}

Fig. 1.A (Fig. 1.B) ranks the 28 countries according to the mean values of the economic and financial development index (I), as well as our main capital ratios. Both panels show that the economic index and capital ratios were higher during and after the subprime crisis period, suggesting more cautionary policies by governments and Islamic banks toward the wide spread effect of the 2007 to 2009 financial crisis. Fig. 1.A also confirms that many countries where Islamic banks operate suffer from weak financial development, compared to other countries, such as the UK and The US.

\subsection{Determinants of Islamic bank capital ratios}

Table 3 reports the results estimating the determinants of Islamic bank capital ratios using Eq. (1). We use the common equity and Tier 1 capital ratios as dependent variables and introduce the different components of economic and financial development, as well as the overall index, in separate regressions to avoid multicollinearity. Models (5) and (10) control for macroeconomic conditions, while the remaining models control for the institutional environment and year fixed effects. We note some important results.

First, we find a negative and significant association between bank size and both unregulated and regulated capital ratios, reflecting the Beck et al. (2013) and Abedifar et al. (2013) arguments that larger Islamic banks are more experienced and more reputable than smaller ones, thus they have lower

\footnotetext{
${ }^{6}$ Economic index (I) represents the Heritage Foundation’s Economic freedom index while Economic index (II) represents the Fraser institute's Economic freedom in the world. Therefore, we add (I) and (II) to differentiate between both indicators.
} 
capital ratios. Large Islamic banks also benefit from diversification and economies of scale, have lower bankruptcy costs, better access to capital markets, and are better positioned to access or develop Sharia'a compliant debt instruments and lever investment accounts. Another explanation is provided by Belkhir et al. (2016), who explain that information asymmetry between firm insiders and the capital markets is a major problem in the MENA region. Our results confirm their findings and suggest that large Islamic banks do not gain transparency as they grow larger; therefore, they rely less on raising equity, which strongly supports the trade-off theory and our expectation of a negative association between size and bank capital.

We also find a positive and significant relationship between profitability and both unregulated and regulated capital ratios. Consistent with the pecking order theory and our expectations, the results persist in almost all models, reflecting the fact that Islamic banks rely more on retained earnings, especially if the economic and financial environment is still not well developed. In such cases, Islamic banks are more prone to information asymmetry and transaction costs, which makes raising either debt or equity more expensive. Also, the coefficient estimates of risk, measured using net loans to assets, show a negative, but not significant, association with Islamic bank unregulated and regulated capital ratios. The coefficient estimate become negative and significant only in Model 3, suggesting that banks possessing important loan portfolios are less exposed to risk than banks that prefer to invest in derivatives, other types of securities, and non-traditional activities, thus reducing the need to hold more capital. In addition, the coefficient estimates reveal strong evidence of a positive and significant association between liquidity and bank capital ratios. For example, the findings suggest that a 1\% increase in asset liquidity in Models (5) and (10) is associated with an increase in the common equity and Tier 1 capital ratios of 0.041 and 0.043 , respectively. In line with pecking order theory and the risk absorption hypothesis, Islamic banks that hold more liquid assets are less exposed to information asymmetry and, therefore, have a better capacity to raise equity than less liquid Islamic banks. Finally, the coefficient estimate for asset tangibility is positive, but it is rarely significant across the models. Consistent with pecking order theory and expectations, the reliance of Islamic banks on asset-backed transactions and investments in real estate lead to a lower risk engagement and impede moral hazard problems. Therefore, the presence of tangible assets is positively associated with bank capital ratios.

[Insert Table 3 here] 
With regard to the institutional environment, we report that economic and financial development has a positive and significant impact on Islamic bank capital ratios. Accordingly, Islamic banks in countries that benefit from rule of law, limited and efficient government intervention, and open and competitive markets have higher unregulated and regulated capital ratios. The findings in Model (5) and (10) suggest that a 1\% increase in the overall index corresponds with an increase in the common equity and Tier 1 capital ratios of 0.265 and 0.447 , respectively. Our results confirm our expectation that Islamic bank decisions to increase capital ratios are strongly associated with property rights, the enforcement of contracts, fighting corruption, reducing tax payments and government spending, encouraging new businesses, the free movement of capital, the efficient allocation of resources, increased competition, and transparency of information. Altogether, these findings suggest that economic and financial development play a significant role in favoring equity capital over debt in the case of Islamic banks. As for the additional macroeconomic control variables, we find that Islamic banks operating in countries with higher oil rents have higher Tier1 capital, while Islamic banks operating in countries with lower mineral rents have higher common equity. The results, however, are not significant for the remainder of the macroeconomic variables.

\subsection{Differences across periods of financial and political distress}

We now control for the fluctuation of the economy between periods of growth and financial distress and examine whether the determinants of Islamic bank capital ratios remain intact. Since our sample includes the subprime crisis period, Table 4 separates the sample for the periods before (19992006), during (2007-2009), and after (2010-2013) the crisis. We report similar results, although some results become insignificant.

Another important issue is that some countries where Islamic banks operate have witnessed significant economic and political instability due to the Arab Spring. While Gosh (2015) demonstrates that political instability has a negative effect on bank risk and performance, Bitar et al. (2016) find that high capital ratios decreased risk and improved bank performance during the Arab Spring. We extend the work of both authors and investigate whether the determinants of Islamic bank capital ratios hold across economic and political cycles. We use two measures of political distress. The first measure, major protests, controls for countries characterized by major protests, such as Algeria and Bahrain, but did not experience major political change as a result. The second measure, Arab Spring, controls for countries characterized by major political changes that resulted in regime change, or civil 
war, such as Egypt, Tunisia, and Syria. The results are also presented in Table 4 and provide three important insights. Firstly, the profitability ratio reports a significantly negative, or insignificant effect, on the bank common equity to assets and Tier1 capital ratios, respectively, perhaps because Islamic banks are using profits to distribute dividends, or pay higher returns to investment account holders and other depositors, instead of retaining earnings, as a signal of bank financial soundness during political distress periods. Secondly, risk is positively associated with bank capital, indicating that Islamic banks expect the default of some of their financial products during periods of political instability and, thus, tend to maintain higher capital ratios. Finally, the economic development index no longer exhibits a significant relationship with the Tier1 capital ratio, demonstrating that law and order policies cannot have a positive effect without the existence of a stable political system.

\section{[Insert Table 4 here]}

\section{Robustness checks and further analyses}

In this section, we examine whether the determinants of Islamic bank capital ratios persist when we use alternative institutional control variables and alternative capital ratio measures. We also explore the determinants of highly capitalized Islamic banks, compared to banks with capital ratios close to the regulatory minimum. Finally, we examine the determinants of changes in Islamic bank capital ratios and the role of legal and political systems.

\subsection{Alternative capital ratios and control variables}

In this section, we investigate whether our findings on the relation between financial development and the capital ratios of Islamic banks persist when we re-estimate our regression using alternative independent and dependent variables. First, we use the Fraser Institute index of economic freedom (II), instead of the Heritage Foundation economic freedom index (I), to control for institutional environment. The new index is the average of five sub-indexes (i.e. size of government,

legal system and property rights, sound money, freedom to trade internationally, and regulation). The results presented in Table 5 continue to lend support to our previous findings. Small, more profitable, and highly liquid banks have higher unregulated and regulated capital ratios. As for the Fraser Institute’s economic and financial development index and its components, we also report a positive effect on Islamic bank capital ratios in almost all models, confirming our earlier results. 


\section{[Insert Table 5 here]}

Second, we use total equity to assets and capital adequacy ratios as alternative dependent variables. The capital adequacy ratio is Tier 1 plus Tier 2 capital, divided by risk-weighted assets and off-balance sheet exposures, and it must be at least 8\% under the Basel III rules. Tier 2 capital is the sum of hybrid capital, subordinated debt, loan loss reserves, and valuation reserves. Song and Oosthuizen (2014) and López-Majía et al. (2014) ascertain that Islamic banks have a very small Tier 2 capital ratios, because they are prohibited from instruments such as subordinated debt (e.g. junior security and subordinated loans) that require interest payments. Therefore, their capital adequacy ratios are not very different from their Tier1 capital ratios. The results presented in Table 6 are highly significant and the determinants of bank capital are not sensitive to alternative capital ratio measures, or different sets of institutional control variables.

\section{[Insert Table 6 here]}

\subsection{The determinants of highly capitalized Islamic bank capital ratios}

We now investigate whether our findings are similar for highly capitalized banks. Berger et al. (2008) provide three arguments for being highly capitalized. First, higher capital ratios reflect higher retained earnings as a precautionary policy against future equity shortages. Second, banks are more sensitive to factors, such as earnings volatility, deposit shortfalls, charter values, and regulatory policies (e.g. too-big-to-fail), which create incentives for bank managers to adapt their capital ratios according to these factors. Finally, banks that plan to have future mergers prefer to maintain higher capital buffers to ensure regulatory approval. We define highly capitalized banks using a dummy variable that equals one if the bank’s Tier1 capital ratio exceeds its upper quantile (Q75) and zero otherwise. We use Eq. (2) to estimate the results, and Table 7 presents the findings for the initial and alternative measures of capital ratio. Since the dependent variable is now a binary variable, we use, in addition to GLS, logit and probit regressions to check the robustness of the results. We find that highly capitalized banks are smaller. Highly capitalized banks also have higher retained earnings, are more liquid, and have higher tangible asset ratios than smaller Islamic banks. This is logical, since small Islamic banks are constrained by Sharia'a law and are less capable of developing debt-based Sharia'a compliant instruments. Therefore, they prefer higher liquidity and rely on retained earnings to increase their capital ratios, instead of using external funds. Finally, the effect of the economic and 
financial development index suggests that Islamic banks tend to increase their capital ratios in countries with better institutional environments. In all, the results coincide with our main findings and suggest that these findings are driven by highly capitalized Islamic banks.

$$
\begin{aligned}
\text { Highly_CAP }_{\mathrm{ijt}} & =\alpha+\beta_{1} \times \text { Bank_Trad }_{\mathrm{ijt}-1}+\beta_{1} \times \text { Institutional_det }_{\mathrm{jt}-1}+\beta_{3} \times \text { Macro_eco }_{\mathrm{jt}-1} \\
& +\sum_{\mathrm{T}=1}^{\mathrm{T}} \beta_{3} \times \mathrm{YFE}_{\mathrm{t}}+\varepsilon_{\mathrm{it}}(2)
\end{aligned}
$$

[Insert Table 7 here]

\subsection{The determinants of minimally capitalized Islamic bank capital ratios}

We complement the previous analysis by examining whether the determinants of Islamic bank capital ratios are similar when Tier1 capital and capital adequacy ratios are close to the minimum regulatory capital requirements. We use Eq. (3) to estimate the determinants of bank capital ratios, and Table 8 reports the results. In Eq. (3), we interact all independent variables with a dummy variable, close, that is equal to one if the bank Tier1 capital and capital adequacy ratios are close to the minimum regulatory capital requirements. We employ two definitions of the close dummy. One corresponds to banks having less than the lower quantile (Q1) of the Tier1 capital ratio, and the other corresponds to banks having less than the lower quantile (Q1) of the capital adequacy ratio in the previous year. We choose to define close as banks with capital regulatory ratios below the lower quantile, instead of the minimum regulatory capital - equal to 4\% for Tier1 capital and 8\% for the capital adequacy ratio - required by the BCBS and the IFSB, because most Islamic banks prefer to hold regulatory capital ratios that are above the minimum imposed by both the BCBS and IFSB (Beck et al. 2013, Bitar et al. 2016). Furthermore, some countries, such as Bahrain, already require banks to hold minimum capital of $12 \%$, well above the $8 \%$ recommended by both guidelines. We find that the determinants of capital ratios for Islamic banks with capital ratios approaching the minimum regulatory requirements are inconsistent for both unregulated and regulated capital ratios. For example, we find that bank size is now positively associated with Islamic bank capital ratios, while profitability, liquidity, and tangibility are each positively associated with the capital ratios of the least capitalized Islamic banks. These results reflect the leverage position of Islamic banks, where larger banks tend to adjust by increasing capital ratios when their regulatory capital approaches the minimum regulatory requirements. In addition, the negative associations for the other bank 
determinants suggest that Islamic banks with lower capital ratios (or higher leverage) become more fragile in in terms of generating profits and benefit less from being more liquid and tangible, compared to highly capitalized (low leveraged) banks. Finally, the negative effect of the economic and financial development index indicates that Islamic banks with capital ratios close to the minimum capital requirements are bound to use leverage over equity in countries with better institutional environments.

$$
\begin{aligned}
\text { CAP }_{\text {Islamic }_{\mathrm{ijt}}=} & \alpha+\beta_{1} \times \text { Bank }_{\text {Trad }_{\mathrm{ijt}-1}}+\beta_{1} \times \text { Institutional }_{\mathrm{det}_{\mathrm{jt}-1}}+\beta_{1} \times \text { Bank }_{\mathrm{Trad}_{\mathrm{ijt}-1}} \times \text { Close }_{\mathrm{ijt}-1} \\
& +\beta_{1} \times \text { Institutional }_{\mathrm{det}} \mathrm{jt}-1 \\
& \times \text { Close }_{\mathrm{ijt}-1}+\beta_{3} \times \text { Macro_eco }_{\mathrm{jt}-1} \\
& +\sum_{\mathrm{T}=1}^{\mathrm{T}} \beta_{3} \times \mathrm{YFE}_{\mathrm{t}}+\varepsilon_{\mathrm{it}}(3)
\end{aligned}
$$

[Insert Table 8 here]

\subsection{The determinants of Islamic bank capital changes}

As we study the effect of the determinants of Islamic bank capital ratios, it also makes sense to examine how changes in those determinants can affect changes in Islamic bank capital ratios. For example, Barth et al. (2013) argue that it is interesting to explore the efficiency with which banks react to changes in regulatory reforms. Another reason for studying changes in capital ratios is that Islamic banks are often more capitalized than their conventional counterparts. Therefore, it is important to study how changes in the determinants affect the changes in capital ratios, in addition to their absolute values. We use a first difference estimation over three time intervals, corresponding to the periods before, during, and after the 2007 to 2009 financial crisis, for all dependent and independent variables. For each bank, the variables are averaged for the three time periods. Due to the first differentiation estimation, the final sample contains observations for two out of three time periods. The findings are presented in Table 9 for our initial and alternative capital ratios, and the results provide several new insights. First, changes in bank size, profitability, liquidity, and asset tangibility have a positive and consistent effect on Islamic bank capital changes, suggesting that changes in bank financial characteristics in periods of financial distress have a direct effect on their common equity and Tier1 capital ratios. Secondly, in contrast to our earlier findings, changes in the institutional environment might result in a negative effect on Islamic bank capital ratios. This may be explained by the fact that inconsistencies in economic and financial development in terms of rule of 
law, government intervention, regulation, and markets can be interpreted as a weak and unstable institutional environment, implying higher transaction costs and information asymmetries, making the cost of raising equity more expensive, relative to debt. Finally, changes in GDP growth correspond with higher capital ratios, while fluctuations in inflation rates result in a negative effect on bank capital. In addition, changes in both oil and mineral rents are negatively associated with bank capital changes, suggesting that oil and mineral fluctuations severally impact Islamic bank capital ratios, especially risk-based capital ratios. This reflects the risk of a heavy reliance on oil and mineral industries within Islamic bank portfolios of investments.

\section{[Insert Table 9 here]}

\subsection{The effect of legal and political systems}

We examine the robustness of previous results by separating the sample into several sub samples, depending on country economic conditions and classifications, legal and political systems, as well as bank stability. First, we focus on the GCC countries, because they have the largest number of Islamic banks (Alqahtani et al., 2016; Ernst and Young, 2015). In addition, Bitar et al. (2016) argue that banks in these countries tend to attract talented managers, skilled employees, and are working on developing their regulatory frameworks to enhance their risk management and improve their capacity to absorb financial shocks. Results presented in Table 10, Panel A, Models (1) and (6) report similar results, except the economic and financial development index is no longer significant, suggesting that additional efforts are required in terms of rule of law, regulatory environment, and market development, especially since the institutional environment in this region is still ranked behind the industrialized countries (Creane et al., 2004, Bitar et al., 2016). Second, Table 10, Panel A, Models (2) and (7) show no significant differences from previous results with regard to developing countries. Third, we categorize countries according to their legal systems: 1) western, which refers to the common and civil law countries; 2) hybrid, which refers to a mix between common or civil law and Sharia'a law (e.g. Indonesia, Malaysia, and Turkey); and 3) Sharia'a, which refers to countries that fully adopt Islamic Sharia'a law (e.g. Iran and Saudi Arabia). Results presented in Panel A, Models (3) to (6), and (8) to (10) show that our previous findings are mostly driven by countries operating under hybrid legal systems, indicating that small and more profitable Islamic banks have higher capital ratios in countries with better institutional environments and hybrid legal systems. Fourth, we collect data on country political systems from the Political Regime Characteristics and Transitions of 
Polity IV project. We refer to two broad political systems: 1) highly democratic; and 2) highly autocratic. $^{7}$ In addition, we refer to a measure of political durability to capture the stability and the durability of the political systems in different countries. The findings are reported in Table 10, Panel $\mathrm{B}$ and show no significant change in the effect of different explanatory variables on Islamic bank capital ratios across different political regimes, although the results are less significant when determining the Tier1 capital ratio. Finally, we separate highly stable ${ }^{8}$ Islamic banks from the other Islamic banks and find no significant difference, although the coefficient estimates for bank level determinants appear to be more significant for highly stable Islamic banks.

\section{[Insert Table 10 here]}

\subsection{The effect of publicly listed versus unlisted Islamic banks}

Aside from the previous mentioned effects, the determinants of Islamic bank capital decisions can also depend on market discipline. In fact, listing a bank in the public market implies more stringent rules and stricter capital regulation and supervision. Therefore, we divide the sample into publicly listed and unlisted Islamic banks. For listed banks, we refer to Bloomberg database and use market-to-book and dividend per share as two market-based control variables to control for the market effect. We also use fee income to total operating income and non-interest income to total operating income to control for the Islamic bank business model and activity diversification. Results are reported in Table 11. We notice that the bank capitalization determinants are most significant for publicly listed banks, suggesting that the effect of bank size, profitability, risk, liquidity, tangibility and economic development on capital ratios of Islamic banks is also driven by the disciplinary role that the financial markets play in the capital structure decisions of publicly listed Islamic banks, compared to unlisted Islamic banks.

[Insert Table 11 here]

\footnotetext{
${ }^{7}$ A democratic political system is mainly characterized with the freedom of expression where all citizens have the right to express their opinion and choose their leaders. In contrast, the modern autocratic political system is characterized with a high degree of restriction or suppression of other political parties. It also exercises a high degree of directiveness over social and economic activities.

${ }^{8}$ Highly stable Islamic banks are banks with values that exceed the upper quantile of their three years rolling Z-score.
} 


\subsection{IV approach and other estimation techniques}

We verify the robustness of our results by addressing the issue of potential endogeneity and by employing alternative econometric specifications and standard errors.

First, we use an instrumental variable (IV) approach to mitigate any concerns about endogeneity. In an IV approach, we regress the economic and financial development characteristics on instruments and the other regressors, as reported in the base models (i.e. Table 2). Then, the predicted values of the economic development variable replaces the index reported in base models. The current literature on Islamic bank financial characteristics is largely silent regarding endogeneity and lacks guidance on the specific instruments that can be used when examining the association between economic development and bank capital structure. In this study, we use the first and the second lagged values of the World Governance Index, as well as the rest of regressors, as instruments. Computed by the World Bank, the World Governance Index, reports aggregate and individual governance indicators for 215 economies worldwide. The index is basically the result of a survey by Kaufmann et al. (2006), reflecting the responses of a large number of enterprises, citizens, and experts in industrialized and developing countries. We use this index, because it captures the institutional environments that play a key role in shaping the financial development of economies. Moreover, we argue that it is less likely that changes in the World Governance Index would have a direct, immediate effect on contemporaneous Islamic bank capital decisions. Instead, it might affect bank capital through its impact on economic and financial development. We follow Barth et al. (2009) and conduct an F-test of the excluded exogenous variables in the first-stage regressions. The null hypothesis of the test is that our instruments do not explain cross-sectional differences in capital regulatory guidelines and measures. We reject the null hypothesis at the $1 \%$ level in all models. ${ }^{9}$ The results of the secondstage regressions are reported in Table 12, Panel A. We use three estimation techniques for both capital ratios: (1) we use Two Least Squares (2SLS) regression; (2) we also use Limited Information Maximum Likelihood (LIML); and (3) we utilize Generalized Method of Moments (GMM). The results from the second stage regressions consistently show that smaller, more profitable, and highly liquid Islamic banks are more highly capitalized. In addition, better economic and financial environments within a country correspond with higher Islamic bank capitalization. These results

\footnotetext{
${ }^{9}$ We do not claim that the lagged values of the world governance index are the best instrumental variables. Instead, we argue that this instruments can be effective in explaining countries' institutional environment.
} 
provide additional support for our earlier findings and suggest that results are not driven by endogeneity.

\section{[Insert Table 12 here]}

Secondly, we employ four alternative econometric specifications and standards errors. In the first two estimations, we use truncated regressions to address any bias related to the upper and lower distribution of observations for the dependent variable and median quantile regression, because it provides more robust results to outliers and distributions with heavy tails. In the third and fourth estimations we focus on the standard errors and use a white procedure to correct the heteroscedasticity of the standard errors, as well bootstrapped standard errors using a random resample of 100 of the banks employed in our sample. Table 12, Panel B shows that the estimated coefficients for the independent variables report the same signs across all estimations and models, indicating that the effects of bank size, profitability, risk, liquidity, asset tangibility, and economic development on the capital ratios of Islamic banks are unaffected by the use of different econometric specifications and standards error treatment.

\section{Policy implications and conclusion}

A large amount of research in corporate finance highlights the importance of studying the determinants of firm and bank capital structures, and empirical evidence shows that most determinants of bank capital structure are identical to the findings of other studies in corporate finance. However, the literature currently lacks empirical support for the determinants of the capital structures of banks in developing countries and Islamic banks, in particular. Recent trends in global markets have led to increasingly open markets that have resulted in interdependence across world financial markets, many

of which are still developing. Furthermore, the recent global financial crisis corresponds with renewed interest in understanding bank capital decisions and controlling financial sector risk, especially in vulnerable, developing countries. In addition, Islamic banks, which often operate in developing countries, face Sharia'a restrictions that lead Islamic banks to adopt more conservative capitalization policies. Therefore, it is necessary to ensure that Islamic bank capitalization decisions are driven by factors similar to those of conventional banks.

Accordingly, we examine the impact of bank characteristics, such as size, profitability, risk, liquidity, and asset tangibility, on Islamic bank capital in order to determine if capital determinants are 
similar to those predicted by the conventional banking and corporate finance literature. Additionally, we examine the impact of economic and financial development measures, such as rule of law, government efficiency, currency stability, and market openness, in determining Islamic bank financing choices. Since Islamic finance is becoming increasingly popular, especially in emerging economies, it is necessary to understand how the development of the institutional environments of developing countries will impact the capitalization of the international banking system.

We utilize an international sample of more than 100 Islamic banks, operating in 28 MENA and SEA countries from 1999 to 2013. We use an empirical framework to estimate how bank and country characteristics affect Islamic bank capitalization, and we find that that small, more profitable, and more liquid Islamic banks, operating in countries with better institutional environments and market discipline are better capitalized. Our results are mainly driven by highly capitalized Islamic banks. When Islamic banks hold capital at levels well above those required by regulators, Islamic bank capital decisions appear to be driven by similar factors to those previously found in the capital structure literature, which implies that highly capitalized Islamic banks are able to choose capital structure in a ways consistent with established capital structure theory. However, when bank capitalization is near the regulatory minimum, results are inconsistent, implying that these firms face regulatory and liquidity constraints that change the way managers make financing decisions.

Our results also highlight the important role that the institutional environment plays in determining Islamic bank capitalization. We find that improvements in measures of economic and financial development, such as legal system, property rights, currency stability, government corruption, and market openness, are positively associated with Islamic bank capitalization. In addition, we also find that the determinants of Islamic bank capital ratios are different across periods of financial and political distress, confirming the role that institutional environment plays in the stability of financial systems. The findings are robust to the use of alternative capital ratio measures, different measures of institutional development, endogeneity, alternative estimation techniques, and different subsamples of countries, ranked according to their legal and political systems.

The results presented extend the literature on bank capitalization in developing and Islamic financial markets and has important policy implications. As current international financial markets and regulatory standards evolve in order to develop sound financial systems and bank governance, our results help explain how Islamic bank managers choose between debt and equity financing, especially 
in developing countries. Islamic bank preferences for internal funds and equity are likely related to the constraints imposed by Sharia'a law, which encourages Islamic banks to increase capital buffers, instead of utilizing leverage. More importantly, our results show that improvements in the political and financial environments that allow for more social and economic freedom result in Islamic banks that are better capitalized, and this is especially true for smaller banks that traditionally have difficulty raising capital in underdeveloped economies.

\section{References}

Abdul-Karim, M., Hassan, M., Hassan, T., and Mohamad, S. (2014) Capital adequacy and lending and deposit behaviors of conventional and Islamic banks, Pacific-Basin Finance Journal 28, 58-75.

Abedifar, P., Molyneux, P., and Tarazi, A., 2013. Risk in Islamic banking. Review of Finance 17, 2035-2096.

Alqahtani, F., Mayes, D.G., and Brown, K. (2016) Economic turnoil and Islamic banking: Evidence from the Gulf Cooperation Council, Pacific-Basin Finance Journal 39, 44-56.

Anginer, D. and Demirgüç-Kunt, A. (2014) Bank capital and systemic stability, Policy Research Working Paper No. 6948, The World Bank, Washington, DC.

Anginer, D., Demirgüç-Kunt, A., Huizinga, H., and Ma, K. (2016) Corporate governance, and bank capitalization strategies, Journal of Financial Intermediation 26, 1-27.

Antoniou, A., Guney, Y., and Paudyal, K. (2008) The determinants of capital structure: capital market- oriented versus bank-oriented institutions, Journal of Financial and Quantitative Analysis 43, 59-92.

Barth, J., Lin, C., Ma, Y., Seade, J., and Song, F. (2013) Do bank regulation, supervision and monitoring enhance or impede bank efficiency? Journal of Banking \& Finance 37, 2879-2892.

Barth, J.R., Lin, C., Lin, P., and Song, F. (2009) Corruption in bank lending to firms: cross-country micro evidence on the beneficial role of competition and information sharing, Journal of Financial Economics 91, 361-388.

Beck, T., Demirgüç-Kunt, A., and Merrouche, O. (2013) Islamic vs. conventional banking: Business model, efficiency and stability, Journal of Banking \& Finance 37, 433-447.

Belkhir, M., Maghyereh, A., and Awartani, B. (2016) Institutions and corporate capital structure in the MENA region, Emerging Market Review 26, 99-129.

Berger, A.N. and Bouwman, C.H.S. (2012) Bank liquidity creation, monetary policy, and financial crises, working paper series.

Berger, A.N., DeYoung, R., Flannery, M., Lee, D., and Öztekin, Ö. (2008) How do large banking organizations manage their capital ratios, Journal of Financial Services Research 34, 123-149.

Bitar, M., Madiès, P., and Taramasco, O. (2016) What makes Islamic banks different? A multivariate approach, Economic Systems, Forthcoming.

Bitar, M., Saad, W., and Benlemlih, M. (2016) Bank risk and performance in the MENA region: The importance of capital requirements, Economic Systems 40, 398-421. 
Cathcart, L., El-Jahel, L., and Jabbour, R. (2015) Can regulators allow banks to set their own capital ratios? Journal of Banking \& Finance 53, 112-123.

Cho, S.S., El-Ghoul, S., Guedhami, O., and Suh, J. (2014) Creditor rights and capital structure: Evidence from international data, Journal of Corporate Finance 25, 40-60.

Čihák, M. and Hesse, H. (2010) Islamic banks and financial stability: An empirical analysis, Journal of Financial Services Research 38, 95-113.

Demirgüç-Kunt, A., Detragiache, E., and Merrouche, O. (2013) Bank capital: lessons from the financial crisis, Journal of Money, Credit and Banking 45, 1147-1164.

Demirgüç-Kunt, A., Klapper, L., and Randall, D. (2013) Islamic finance and financial inclusion: Measuring use and demand for formal financial services among Muslim adults. Policy Research, Working Paper, No. 6642, The World Bank., Washington, DC.

Dermine, J. (2015) Basel III leverage ratio requirement and the probability of bank runs, Journal of Banking \& Finance 5, 266-277.

Ernst \& Young (2012) World Islamic banking competitiveness report 2013.

Ernst \& Young (2015) World Islamic banking competitiveness report. (Retrieved from) http://www.islamicfinance.com/wp-content/uploads/2014/12/EY-worldislamic-bankingcompetitiveness-report-2014-151.pdf.

Fama, E. F. and Jensen, M. (1983) The market for corporate control: the scientific evidence. Journal of Financial Economics 11, 5-50.

Fan, J. P. H., Titman, S., and Twite, G. J. (2012) An international comparison of capital structure and debt maturity choices, Journal of Financial and Quantitative Analysis 47, 23-56.

Frank, M. Z. and Goyal, V. K. (2009) Capital Structure decisions: Which factors are reliably important, Financial Management 38, 1-37.

Gheeraert, L. (2014) Does Islamic finance spur banking sector development? Journal of Economic Behavior \& Organization 103, S4-S20.

Gungoraydinoglu, A. and Öztekin, Ö. (2011) Firm-and country-level determinants of corporate leverage: Some new international evidence, Journal of Corporate Finance 17, 1457-1474.

Hanousek, J. and Shamshur, A. (2011) A stubborn persistence: Is the stability of leverage ratios determined by the stability of the economy? Journal of Corporate Finance 17, 1360-1376.

Horváth, R., Seidler, J., and Weill, L. (2013) Bank capital and liquidity creation: Granger-causality evidence, Journal of Financial Services Research 45, 341-361.

Imam, P., and Kpodar, K. (2015) Is Islamic banking good for growth? Working Paper WP/15/81, International Monetary Fund, Washington, DC.

Jõeveer, K. (2013) Firm, country and macroeconomic determinants of capital structure: Evidence from transition economies, Journal of Comparative Economics 41, 294-308.

Johnes, J., Izzeldin, M., and Pappas, V. (2014) A comparison of performance of Islamic and conventional banks 2004 to 2009, Journal of Economic Behavior \& Organization 104, S93107.

Kraus, A. and Litzenberger, R. H. (1973) A state-preference model of optimal financial leverage, The Journal of Finance 28, 911-922. 
Modigliani, F. and Miller, M. (1958) The cost of capital, corporation finance and the theory of investment, American Economic Review 48, 261-297.

Mollah, S. and Zaman, M. (2015) Shari'ah supervision, corporate governance, and performance: Conventional vs. Islamic banks, Journal of Banking \& Finance 58, 418-435.

Mollah, S., Hassan, M. K., Al-Farooque, O., and Mobarek, A. (2016) The governance, risk-taking, and performance of Islamic banks, Journal of Financial Services research 49, 1-25.

Myers, S. C. (1984) The Capital structure puzzle, Journal of Finance 39, 575-592.

Myers, S. C. and Majluf, N. (1984) Corporate financing and investment decisions when firms have information that investors do not have, Journal of Financial Economics 13, 187-224.

Octavia, M. and Brown, R. (2010) Determinants of bank capital structure in developing countries: regulatory capital requirement versus the standard determinants of capital structure, Journal of Emerging Markets 15, 1-50.

Öztekin, Ö. (2015) Capital structure decisions around the world: Which factors are reliably important? Journal of Financial \& Quantitative Analysis 50, 301-323.

Öztekin, O. and Flannery, M. J. (2012) Institutional determinants of capital structure adjustment speeds, Journal of Financial Economics 103, 88-112.

Polity IV project. Political regime characteristics and transitions, 1800-2013, College Park: University of Maryland, Center for Systemic Peace, www.systemicpeace.org.

Schepens, G. (2016) Taxes and bank capital structure, Journal of financial Economics 120, 585-600.

Song, I. and Oosthuizem, C. (2014) Islamic banking regulation and supervision: Survey results and challenges. Working paper WP/14/220, International Monetary Fund, Washington, DC. 


\section{Tables}

Table 1

Predicted effects of explanatory variables on bank capital: corporate/conventional banking vs. Islamic banking

\begin{tabular}{lllll}
\hline Categories & Variables & Corporate finance & Conventional banking & $\begin{array}{l}\text { Islamic banking } \\
\text { (predicted effect) }\end{array}$ \\
\hline Bank-Traditional determinants & Size & - & - & - \\
& Profitability & $-/+$ & $-/+$ & + \\
& Liquidity & $-/+$ & $-/+$ & $?$ \\
& Tangibility & + & + & + \\
Macroeconomics & Risk & $-/+$ & $-/+$ & $?$ \\
& GDP growth & + & + & + \\
& Inflation & $-/+$ & $-/+$ & + \\
& Oil rent & n.a. & n.a. & + \\
Institutional environment & Mineral rent & n.a. & n.a. & + \\
& Gas rent & n.a. & n.a. & + \\
& Rule of law & $-/+$ & $-/+$ & $?$ \\
& Limited Government & n.a. & n.a. & $?$ \\
& Regulatory efficiency & n.a. & n.a. & $?$ \\
& Open markets & n.a. & n.a. & $?$ \\
& Economic development & n.a. & n.a. & $?$ \\
\hline
\end{tabular}


Table 2

Summary statistics for regression variables

\begin{tabular}{|c|c|c|c|c|c|c|c|c|c|c|c|c|c|c|c|c|c|}
\hline & $\begin{array}{l}\text { Common } \\
\text { equity }\end{array}$ & $\begin{array}{l}\text { Tier 1 } \\
\text { capital }\end{array}$ & $\begin{array}{l}\text { Equity to } \\
\text { assets }\end{array}$ & $\begin{array}{l}\text { Capital } \\
\text { adequacy }\end{array}$ & Size & Profit & Risk & Liquidity & Tangibility & $\begin{array}{l}\text { Eco. } \\
\text { Dev. (I) }\end{array}$ & $\begin{array}{l}\text { Eco. dev. } \\
\text { (II) }\end{array}$ & $\begin{array}{l}\text { GDP } \\
\text { growth }\end{array}$ & Inflation & Legal & $\begin{array}{l}\text { Oil } \\
\text { Rent }\end{array}$ & $\begin{array}{l}\text { Gas } \\
\text { Rent }\end{array}$ & $\begin{array}{l}\text { Miner. } \\
\text { Rent }\end{array}$ \\
\hline & \multicolumn{17}{|c|}{ Panel A. Summary statistics by country } \\
\hline Albania & 23.39 & & 20.96 & . & 10.91 & -3.29 & 39.17 & & 4.91 & 60.11 & 69.9 & 5.03 & 3.15 & 0 & 2.11 & 0.02 & 0.24 \\
\hline Algeria & 22.63 & & 22.73 & & 13.16 & 1.54 & 83.15 & 51.15 & 3.9 & 55.67 & 52 & 3.61 & 9 & 1 & 22.99 & 13.35 & 0.12 \\
\hline Bahrain & 50.1 & 37.59 & 52.06 & 39.23 & 13.14 & 1.29 & 35.19 & 106.9 & 2.23 & 74.63 & 76.13 & 4.96 & 6.88 & 1 & 17.65 & 9.89 & 0 \\
\hline Bangladesh & 6.27 & 9.29 & 6.47 & 11.07 & 13.07 & 0 & 66.26 & 25.57 & 1.76 & 50 & 61.53 & 5.82 & 5.43 & 1 & 0.11 & 3.02 & 0 \\
\hline Bosnia & 32.21 & & 32.37 & 19.12 & 11.76 & -0.8 & 75.63 & 102.2 & 4.91 & 48.53 & 66.32 & 3.89 & 5.21 & 0 & 0 & 0 & 0.55 \\
\hline Egypt & 5.24 & 10.3 & 5.5 & 13.06 & 14.56 & 0.16 & 45.86 & 19.67 & 1.89 & 55.79 & 64.4 & 4.41 & 8.14 & 1 & 8.22 & 5.57 & 0.2 \\
\hline Indonesia & 19.23 & 18.13 & 19.24 & 29.15 & 13.09 & 1.17 & 65.47 & 68.18 & 1.53 & 54.75 & 64.47 & 5.11 & 10.67 & 0 & 4.14 & 2.63 & 1.65 \\
\hline Iraq & 37.85 & & 37.85 & 12.5 & 12.42 & 3.73 & 11.96 & 147.8 & 6.57 & 16.8 & & 6.27 & 10.14 & 1 & 53.09 & 0.31 & 0 \\
\hline Jordan & 11.56 & 31.74 & 11.58 & 33.63 & 14 & 0.88 & 46.07 & 42.9 & 1.56 & 66.7 & 75.21 & 5.26 & 4.76 & 1 & 0 & 0.23 & 1.26 \\
\hline Kenya & 21.72 & 24.77 & 21.94 & 25.88 & 11.61 & -1.07 & 63.49 & & 4.51 & 58.23 & 69.51 & 4.18 & 6.44 & 0 & 0 & 0 & 0.07 \\
\hline Kuwait & 25.7 & 25.7 & 28.08 & 26.57 & 14.73 & 0.74 & 33.21 & 41.09 & 5.18 & 66.17 & 74.11 & 4.63 & 10.1 & 1 & 49.39 & 2.52 & 0 \\
\hline Lebanon & 32.71 & & 32.79 & 18.01 & 11.58 & -0.53 & 17.68 & 116.1 & 7.1 & 58.62 & 72.13 & 4.34 & 2.14 & 1 & 0 & 0 & 0 \\
\hline Malaysia & 11.96 & 17.41 & 12.13 & 19.65 & 14.72 & 0.24 & 54.49 & 39.4 & 0.42 & 63.71 & 68.28 & 5.13 & 3.48 & 1 & 6.63 & 5.62 & 0.11 \\
\hline Mauritania & 25.5 & & 25.5 & & 11.44 & 1.5 & 51.33 & 58.98 & 7.27 & 53.19 & 61.2 & 4.37 & 6.14 & 1 & 4.35 & 0 & 25.22 \\
\hline Pakistan & 15.19 & 23.47 & 15.33 & 23.45 & 12.09 & 1.14 & 27.53 & 51.77 & 2.98 & 55.48 & 59.89 & 4.05 & 10.94 & 1 & 0.83 & 4.11 & 0.05 \\
\hline Qatar & 20.52 & 21.98 & 21.06 & 22.33 & 15.46 & 3.06 & 58.77 & 37.36 & 0.72 & 65.15 & 76.42 & 11.31 & 8.89 & 1 & 30.17 & 16.14 & 0 \\
\hline KSA & 21.82 & 26.47 & 22.32 & 26.01 & 15.81 & 2.31 & 58.65 & 45.24 & 2.45 & 63.35 & 70.03 & 5.1 & 6.58 & 2 & 43.8 & 3.6 & 0.02 \\
\hline Senegal & 10.69 & & 10.69 & & 11.7 & 1.09 & 74.84 & & 1.98 & 57.45 & 59.64 & 3.94 & 2.29 & 0 & 0 & 0.03 & 0.86 \\
\hline Sudan & 15.32 & 35.97 & 16.2 & 34.34 & 12.5 & 2.05 & 30.19 & 65.06 & 4.95 & 43.4 & & 3.56 & 15.96 & 1 & 14.51 & 0 & 0.52 \\
\hline Syria & 18.34 & 48.43 & 18.08 & 51.35 & 13.17 & 0.44 & 25.36 & 111.3 & 3.04 & 44.8 & 56.89 & 3.05 & 7.01 & 1 & 22.11 & 3.48 & 0 \\
\hline Tunisia & 20.6 & 22.33 & 20.61 & 22.33 & 12.73 & 1.07 & 48.42 & 51.98 & 2.77 & 58.95 & 65.6 & 4.11 & 3.54 & 1 & 3.76 & 1.25 & 0.65 \\
\hline Turkey & 10.78 & 14.06 & 11.52 & 14.54 & 15.56 & 1.73 & 73.04 & 20.87 & 1.75 & 58.8 & 64.12 & 3.9 & 19.76 & 0 & 0.16 & 0.02 & 0.14 \\
\hline UAE & 14.01 & 19.66 & 14.72 & 21.87 & 15.43 & 1.1 & 62.78 & 28.68 & 1.74 & 68.51 & 77.34 & 4.55 & 7.96 & 1 & 20.59 & 3.84 & 0 \\
\hline UK & 45.16 & 47.72 & 45.7 & 55.52 & 12.82 & -4.16 & 19.87 & 183.6 & 0.95 & 77.51 & 81.49 & 1.9 & 2.2 & 0 & 1.02 & 0.49 & 0 \\
\hline \multirow[t]{2}{*}{ Yemen } & 13.29 & 14.59 & 13.85 & 15.73 & 12.3 & 0.22 & 28.06 & 52.38 & 1.62 & 51.5 & 63.32 & 2.7 & 13.36 & 1 & 28.59 & 1.1 & 0 \\
\hline & \multicolumn{17}{|c|}{ Panel B. Descriptive statistics for the full sample } \\
\hline $\mathrm{N}$ & 1326 & 739 & 1327 & 838 & 1327 & 1324 & 1280 & 1237 & 1292 & 420 & 420 & 420 & 420 & 28 & 420 & 420 & 420 \\
\hline Mean & 20.94 & 24.17 & 21.6 & 26.02 & 13.77 & 0.99 & 47.92 & 57.55 & 2.79 & 59.85 & 68.36 & 4.65 & 9.4 & 0.96 & 15.38 & 4.26 & 0.46 \\
\hline Min & 3.78 & 7.7 & 4.04 & 9.43 & 10.76 & -20.1 & 0.03 & 1.46 & 0 & 15.6 & 46.8 & -33.1 & -24.22 & 0 & 0 & 0 & 0 \\
\hline Q1 & 7.47 & 12.16 & 7.71 & 13.59 & 12.33 & 0.37 & 28.49 & 20.56 & 0.67 & 53.2 & 62.5 & 3 & 3.37 & 1 & 2.72 & 0.26 & 0 \\
\hline Median & 12.31 & 16.45 & 13.03 & 17.89 & 13.83 & 1.03 & 52.45 & 35.01 & 1.79 & 60.4 & 68.4 & 4.92 & 7.8 & 1 & 13.07 & 3.21 & 0.01 \\
\hline Q3 & 24.65 & 27 & 25.56 & 28 & 15.15 & 2.08 & 66.95 & 59.88 & 3.64 & 67.4 & 75.4 & 6.43 & 14.09 & 1 & 22.51 & 6.22 & 0.2 \\
\hline Max & 82.42 & 79.8 & 84.41 & 86 & 16.93 & 14.58 & 98.86 & 546.19 & 17.23 & 88.9 & 88.6 & 54.16 & 54.18 & 2 & 68.84 & 23.91 & 44.64 \\
\hline SD & 21.3 & 19.06 & 21.77 & 20.1 & 1.76 & 4.22 & 24.88 & 80.71 & 3.2 & 11.76 & 7.75 & 4.95 & 10.22 & 0.52 & 14.96 & 4.38 & 2.37 \\
\hline
\end{tabular}


Table 3

The determinants of Islamic bank capital decisions

\begin{tabular}{|c|c|c|c|c|c|c|c|c|c|c|}
\hline \multirow{2}{*}{$\begin{array}{l}\text { Variables } \\
\text { Model \# }\end{array}$} & \multicolumn{5}{|c|}{ Common equity to total assets } & \multicolumn{5}{|c|}{ Tier 1 capital to risk weighted assets } \\
\hline & [1] & [2] & [3] & [4] & [5] & [6] & [7] & [8] & [9] & [10] \\
\hline Logarithm total assets & $\begin{array}{l}-2.27 * * * \\
(0.708)\end{array}$ & $\begin{array}{l}-2.46^{* * *} \\
(0.750)\end{array}$ & $\begin{array}{l}-2.788 * * * \\
(0.783)\end{array}$ & $\begin{array}{l}-2.493^{* * *} \\
(0.728)\end{array}$ & $\begin{array}{l}-2.036 * * * \\
(0.531)\end{array}$ & $\begin{array}{l}-3.273^{* * *} \\
(0.821)\end{array}$ & $\begin{array}{l}-2.576^{* * *} \\
(0.794)\end{array}$ & $\begin{array}{l}-3.052^{* * * *} \\
(0.798)\end{array}$ & $\begin{array}{l}-2.654^{* * * *} \\
(0.786)\end{array}$ & $\begin{array}{l}-2.746^{* * * *} \\
(0.726)\end{array}$ \\
\hline Earning to assets & $\begin{array}{l}0.330 * * \\
(0.141)\end{array}$ & $\begin{array}{l}0.321 * * \\
(0.138)\end{array}$ & $\begin{array}{l}0.265^{* * *} \\
(0.096)\end{array}$ & $\begin{array}{l}0.340 * * \\
(0.136)\end{array}$ & $\begin{array}{l}0.292^{* *} \\
(0.139)\end{array}$ & $\begin{array}{l}0.413^{* *} \\
(0.183)\end{array}$ & $\begin{array}{l}0.383 * * \\
(0.177)\end{array}$ & $\begin{array}{l}0.520 * * * \\
(0.189)\end{array}$ & $\begin{array}{l}0.388 * * \\
(0.177)\end{array}$ & $\begin{array}{l}0.363^{* *} \\
(0.148)\end{array}$ \\
\hline Net loans to assets & $\begin{array}{l}-0.017 \\
(0.030)\end{array}$ & $\begin{array}{l}-0.013 \\
(0.028)\end{array}$ & $\begin{array}{l}-0.055^{* *} \\
(0.028)\end{array}$ & $\begin{array}{l}-0.004 \\
(0.029)\end{array}$ & $\begin{array}{l}-0.015 \\
(0.030)\end{array}$ & $\begin{array}{l}-0.037 \\
(0.052)\end{array}$ & $\begin{array}{l}-0.057 \\
(0.052)\end{array}$ & $\begin{array}{l}-0.054 \\
(0.060)\end{array}$ & $\begin{array}{l}-0.048 \\
(0.052)\end{array}$ & $\begin{array}{l}-0.026 \\
(0.053)\end{array}$ \\
\hline $\begin{array}{l}\text { Liquid assets to deposits } \\
\text { and short term funding }\end{array}$ & $\begin{array}{l}0.039 * * * \\
(0.0132)\end{array}$ & $\begin{array}{l}0.038^{* * *} \\
(0.0127)\end{array}$ & $\begin{array}{l}0.012 \\
(0.008)\end{array}$ & $\begin{array}{l}0.039 * * * \\
(0.013)\end{array}$ & $\begin{array}{l}0.041^{* * *} \\
(0.0127)\end{array}$ & $\begin{array}{l}0.038 * * \\
(0.017)\end{array}$ & $\begin{array}{l}0.036^{* *} \\
(0.016)\end{array}$ & $\begin{array}{l}0.036^{* *} \\
(0.0164)\end{array}$ & $\begin{array}{l}0.038^{* *} \\
(0.0163)\end{array}$ & $\begin{array}{l}0.043 * * * \\
(0.016)\end{array}$ \\
\hline Fixed assets to assets & $\begin{array}{l}0.278 \\
(0.214)\end{array}$ & $\begin{array}{l}0.208 \\
(0.232)\end{array}$ & $\begin{array}{l}0.432 * * * \\
(0.146)\end{array}$ & $\begin{array}{l}0.215 \\
(0.233)\end{array}$ & $\begin{array}{l}0.242 \\
(0.248)\end{array}$ & $\begin{array}{l}0.502 \\
(0.577)\end{array}$ & $\begin{array}{l}0.468 \\
(0.565)\end{array}$ & $\begin{array}{l}0.56 \\
(0.574)\end{array}$ & $\begin{array}{l}0.446 \\
(0.568)\end{array}$ & $\begin{array}{l}0.180 \\
(0.486)\end{array}$ \\
\hline Rule of law & $\begin{array}{l}0.139 * * \\
(0.064)\end{array}$ & & & & & $\begin{array}{l}0.278 * * * \\
(0.086)\end{array}$ & & & & \\
\hline Limited Government & & $\begin{array}{l}-0.038 \\
(0.068)\end{array}$ & & & & & $\begin{array}{l}0.089 \\
(0.079)\end{array}$ & & & \\
\hline Regulatory efficiency & & & $\begin{array}{l}0.291^{* * *} \\
(0.080)\end{array}$ & & & & & $\begin{array}{l}0.393 * * * \\
(0.127)\end{array}$ & & \\
\hline Open markets & & & & $\begin{array}{l}0.105^{*} \\
(0.054)\end{array}$ & & & & & $\begin{array}{l}0.093 \\
(0.059)\end{array}$ & \\
\hline Economic development & & & & & $\begin{array}{l}0.265^{* *} \\
(0.107)\end{array}$ & & & & & $\begin{array}{l}0.447 * * * \\
(0.137)\end{array}$ \\
\hline GDP growth & & & & & $\begin{array}{l}0.071 \\
(0.062)\end{array}$ & & & & & $\begin{array}{l}-0.079 \\
(0.073)\end{array}$ \\
\hline Inflation & & & & & $\begin{array}{l}0.007 \\
(0.026)\end{array}$ & & & & & $\begin{array}{l}-0.016 \\
(0.024)\end{array}$ \\
\hline Oil rent & & & & & $\begin{array}{l}0.051 \\
(0.051)\end{array}$ & & & & & $\begin{array}{l}0.19^{* * *} \\
(0.067)\end{array}$ \\
\hline Mineral rent & & & & & $\begin{array}{l}-0.086^{* *} \\
(0.034)\end{array}$ & & & & & $\begin{array}{l}0.214 \\
(0.232)\end{array}$ \\
\hline Gas rent & & & & & $\begin{array}{l}0.178 \\
(0.135)\end{array}$ & & & & & $\begin{array}{l}0.100 \\
(0.148)\end{array}$ \\
\hline Constant & $\begin{array}{l}41.47 * * * \\
(11.22)\end{array}$ & $\begin{array}{l}52.99 * * * \\
(12.43)\end{array}$ & $\begin{array}{l}38.22^{* * *} \\
(13.14)\end{array}$ & $\begin{array}{l}44.15^{* * *} \\
(10.61)\end{array}$ & $\begin{array}{l}26.10^{* * *} \\
(8.188)\end{array}$ & $\begin{array}{l}54.63 * * * \\
(12.16)\end{array}$ & $\begin{array}{l}51.04^{* * *} \\
(12.65)\end{array}$ & $\begin{array}{l}36.71^{* *} \\
(14.81)\end{array}$ & $\begin{array}{l}53.22 * * * \\
(12.86)\end{array}$ & $\begin{array}{l}27.80 * * * \\
(10.55)\end{array}$ \\
\hline $\mathrm{N}$ & 862 & 862 & 634 & 862 & 851 & 472 & 472 & 428 & 472 & 463 \\
\hline Year dummy & Yes & Yes & Yes & Yes & No & Yes & Yes & Yes & Yes & No \\
\hline Chi2 & $0.00 * * *$ & $0.00 * * *$ & $0.00 * * *$ & $0.00^{* * *}$ & $0.00^{* * *}$ & $0.00^{* * *}$ & $0.00 * * *$ & $0.00 * * *$ & $0.00^{* * *}$ & $0.00 * * *$ \\
\hline 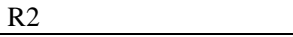 & 0.388 & 0.283 & 0.299 & 0.343 & 0.432 & 0.448 & 0.307 & 0.401 & 0.348 & 0.479 \\
\hline
\end{tabular}


Table 4

Differences during the financial crisis and the Arab spring

\begin{tabular}{|c|c|c|c|c|c|c|c|c|c|c|c|c|c|c|}
\hline \multirow[t]{2}{*}{ Variables } & \multicolumn{7}{|c|}{ Common equity to assets } & \multicolumn{7}{|c|}{ Tier 1 capital to risk weighted assets } \\
\hline & Before & During & After & $\begin{array}{l}\text { Arab } \\
\text { Spring } \\
\end{array}$ & $\begin{array}{c}\text { No major } \\
\text { effect }\end{array}$ & $\begin{array}{l}\text { Major } \\
\text { protests }\end{array}$ & $\begin{array}{c}\text { No major } \\
\text { effect }\end{array}$ & Before & During & After & $\begin{array}{l}\text { Arab } \\
\text { Spring }\end{array}$ & $\begin{array}{c}\text { No major } \\
\text { effect }\end{array}$ & $\begin{array}{l}\text { Major } \\
\text { protests }\end{array}$ & $\begin{array}{c}\text { No major } \\
\text { effect }\end{array}$ \\
\hline Model \# & [1] & [2] & [3] & [4] & [5] & [6] & [7] & [8] & [9] & [10] & [11] & [12] & [13] & [14] \\
\hline Logarithm total assets & $\begin{array}{l}-1.703^{*} \\
(0.875)\end{array}$ & $\begin{array}{c}-2.97 * * * \\
(0.755)\end{array}$ & $\begin{array}{c}-3.49 * * * \\
(0.581)\end{array}$ & $\begin{array}{l}-4.95^{* * * *} \\
(1.908)\end{array}$ & $\begin{array}{c}-1.92^{* * * *} \\
(0.525)\end{array}$ & $\begin{array}{l}-5.701^{* * *} \\
(1.886)\end{array}$ & $\begin{array}{c}-1.901^{* * * *} \\
(0.533)\end{array}$ & $\begin{array}{c}1.312 \\
(1.106)\end{array}$ & $\begin{array}{l}-3.48^{* * * *} \\
(1.123)\end{array}$ & $\begin{array}{l}-3.38^{* * * *} \\
(0.946)\end{array}$ & $\begin{array}{c}-6.51 * * * \\
(0.962)\end{array}$ & $\begin{array}{c}-2.75 * * * \\
(0.678)\end{array}$ & $\begin{array}{l}-5.672^{* * *} \\
(1.245)\end{array}$ & $\begin{array}{c}-2.66^{* * *} \\
(0.697)\end{array}$ \\
\hline Earning to assets & $\begin{array}{c}0.913^{* * * *} \\
(0.243)\end{array}$ & $\begin{array}{l}0.39 * * \\
(0.190)\end{array}$ & $\begin{array}{l}-0.111 \\
(0.103)\end{array}$ & $\begin{array}{c}-0.629 * * \\
(0.277)\end{array}$ & $\begin{array}{c}0.415^{* * *} \\
(0.152)\end{array}$ & $\begin{array}{c}-0.526 * * * \\
(0.172)\end{array}$ & $\begin{array}{l}0.402 * * \\
(0.158)\end{array}$ & $\begin{array}{c}0.743 \\
(0.575)\end{array}$ & $\begin{array}{l}0.66^{* * *} \\
(0.184)\end{array}$ & $\begin{array}{c}0.068 \\
(0.195)\end{array}$ & $\begin{array}{c}0.032 \\
(0.190)\end{array}$ & $\begin{array}{c}0.536 * * * \\
(0.171)\end{array}$ & $\begin{array}{c}0.038 \\
(0.148)\end{array}$ & $\begin{array}{l}0.56 * * * \\
(0.179)\end{array}$ \\
\hline Net loans to assets & $\begin{array}{c}0.01 \\
(0.033)\end{array}$ & $\begin{array}{c}-0.15^{* * * *} \\
(0.058)\end{array}$ & $\begin{array}{c}0.001 \\
(0.034)\end{array}$ & $\begin{array}{l}0.171^{*} \\
(0.099)\end{array}$ & $\begin{array}{l}-0.014 \\
(0.029)\end{array}$ & $\begin{array}{l}0.154^{*} \\
(0.092)\end{array}$ & $\begin{array}{l}-0.013 \\
(0.033)\end{array}$ & $\begin{array}{c}0.063 \\
(0.095)\end{array}$ & $\begin{array}{l}-0.124 \\
(0.095)\end{array}$ & $\begin{array}{l}-0.001 \\
(0.050)\end{array}$ & $\begin{array}{c}0.283^{* *} \\
(0.142)\end{array}$ & $\begin{array}{l}-0.037 \\
(0.055)\end{array}$ & $\begin{array}{l}0.169 * \\
(0.101)\end{array}$ & $\begin{array}{l}-0.042 \\
(0.063)\end{array}$ \\
\hline $\begin{array}{l}\text { Liquid assets to deposits } \\
\text { and short term funding }\end{array}$ & $\begin{array}{c}0.082^{* * * *} \\
(0.009)\end{array}$ & $\begin{array}{l}-0.003 \\
(0.014)\end{array}$ & $\begin{array}{l}0.027 * * \\
(0.010)\end{array}$ & $\begin{array}{c}0.067 * * * \\
(0.014)\end{array}$ & $\begin{array}{c}0.041 * * * \\
(0.013)\end{array}$ & $\begin{array}{c}0.072^{* * *} \\
(0.017)\end{array}$ & $\begin{array}{l}0.04^{* * * *} \\
(0.013)\end{array}$ & $\begin{array}{c}0.165 \\
(0.119)\end{array}$ & $\begin{array}{c}0.001 \\
(0.019)\end{array}$ & $\begin{array}{c}0.053^{* * *} \\
(0.013)\end{array}$ & $\begin{array}{c}0.126^{* * *} \\
(0.022)\end{array}$ & $\begin{array}{l}0.035^{* *} \\
(0.018)\end{array}$ & $\begin{array}{c}0.095^{* * *} \\
(0.020)\end{array}$ & $\begin{array}{l}0.034 * \\
(0.019)\end{array}$ \\
\hline Fixed assets to assets & $\begin{array}{c}0.177 \\
(0.237)\end{array}$ & $\begin{array}{c}0.261 \\
(0.361)\end{array}$ & $\begin{array}{c}0.586 \\
(0.418)\end{array}$ & $\begin{array}{c}0.306 \\
(0.660)\end{array}$ & $\begin{array}{c}0.235 \\
(0.265)\end{array}$ & $\begin{array}{c}0.641 \\
(0.817)\end{array}$ & $\begin{array}{c}0.224 \\
(0.265)\end{array}$ & $\begin{array}{c}2.904 * * * \\
(0.720)\end{array}$ & $\begin{array}{c}0.245 \\
(0.595)\end{array}$ & $\begin{array}{l}1.702^{*} \\
(0.945)\end{array}$ & $\begin{array}{l}1.478^{*} \\
(0.815)\end{array}$ & $\begin{array}{c}0.502 \\
(0.524)\end{array}$ & $\begin{array}{c}1.166 \\
(0.969)\end{array}$ & $\begin{array}{c}0.598 \\
(0.564)\end{array}$ \\
\hline Economic development & $\begin{array}{c}0.168 \\
(0.120)\end{array}$ & $\begin{array}{c}0.441^{* *} \\
(0.187)\end{array}$ & $\begin{array}{c}0.441^{* * * *} \\
(0.103)\end{array}$ & $\begin{array}{l}0.645^{*} \\
(0.337)\end{array}$ & $\begin{array}{c}0.245^{* *} \\
(0.106)\end{array}$ & $\begin{array}{c}0.754 * * \\
(0.303)\end{array}$ & $\begin{array}{c}0.239 * * \\
(0.107)\end{array}$ & $\begin{array}{c}0.561 * * * \\
(0.154)\end{array}$ & $\begin{array}{c}0.481 \\
(0.295)\end{array}$ & $\begin{array}{c}0.404^{* *} \\
(0.184)\end{array}$ & $\begin{array}{l}-0.325 \\
(0.198)\end{array}$ & $\begin{array}{c}0.443 * * * \\
(0.128)\end{array}$ & $\begin{array}{c}-0.221 \\
(0.214)\end{array}$ & $\begin{array}{c}0.436^{* * *} * \\
(0.136)\end{array}$ \\
\hline Constant & $\begin{array}{c}23.73 * * \\
(11.33)\end{array}$ & $\begin{array}{c}41.08 * * * \\
(14.88)\end{array}$ & $\begin{array}{c}37.29 * * * \\
(7.278)\end{array}$ & $\begin{array}{c}33.83^{* *} \\
(17.09)\end{array}$ & $\begin{array}{c}27.39 * * * \\
(8.165)\end{array}$ & $\begin{array}{c}37.79 \\
(23.37)\end{array}$ & $\begin{array}{c}27.27 * * * \\
(8.131)\end{array}$ & $\begin{array}{c}-47.53 * * \\
(20.92)\end{array}$ & $\begin{array}{l}44.60 * \\
(23.75)\end{array}$ & $\begin{array}{c}38.27 * * * \\
(12.25)\end{array}$ & $\begin{array}{c}119.2 * * * \\
(20.63)\end{array}$ & $\begin{array}{c}31.04 * * * \\
(9.840)\end{array}$ & $\begin{array}{c}105.8 * * * \\
(26.89)\end{array}$ & $\begin{array}{c}30.69 * * * \\
(9.863)\end{array}$ \\
\hline $\mathrm{N}$ & 281 & 227 & 354 & 47 & 815 & 64 & 798 & 71 & 148 & 253 & 31 & 441 & 46 & 426 \\
\hline Year dummy & No & No & No & No & No & No & No & No & No & No & No & No & No & No \\
\hline Chi2 & $0.00^{* * *}$ & $0.00^{* * *}$ & $0.00^{* * *}$ & $0.00^{* * *}$ & $0.00 * * *$ & $0.00 * * *$ & $0.00^{* * *}$ & $0.00 * * *$ & $0.00^{* * *}$ & $0.00^{* * *}$ & $0.00^{* * *}$ & $0.00 * * *$ & $0.00 * * *$ & $0.00^{* * *}$ \\
\hline R2 & 0.389 & 0.333 & 0.391 & 0.624 & 0.39 & 0.616 & 0.377 & 0.581 & 0.405 & 0.434 & 0.798 & 0.41 & 0.687 & 0.41 \\
\hline
\end{tabular}

Standard errors are clustered at the bank level and are reported in parentheses below their coefficient estimates.

* Statistical significance at the $10 \%$ level.

** Statistical significance at the $5 \%$ level.

*** Statistical significance at the $1 \%$ level. 
Table 5

The determinants of Islamic bank capital decisions: alternative institutional control variables

\begin{tabular}{|c|c|c|c|c|c|c|c|c|c|c|c|c|}
\hline \multirow{2}{*}{$\begin{array}{l}\text { Variables } \\
\text { Model \# }\end{array}$} & \multicolumn{6}{|c|}{ Common equity to total assets } & \multicolumn{6}{|c|}{ Tier 1 capital to risk weighted assets } \\
\hline & [1] & [2] & [3] & [4] & [5] & [6] & [7] & {$[8]$} & [9] & [10] & [11] & [12] \\
\hline Logarithm total assets & $\begin{array}{l}-2.89 * * * \\
(0.829)\end{array}$ & $\begin{array}{c}-3.61 * * * \\
(0.851)\end{array}$ & $\begin{array}{c}-3.087 * * * \\
(0.839)\end{array}$ & $\begin{array}{c}-2.754 * * * \\
(0.776)\end{array}$ & $\begin{array}{c}-2.968 * * * \\
(0.822)\end{array}$ & $\begin{array}{c}-2.842 * * * \\
(0.625)\end{array}$ & $\begin{array}{c}-2.958 * * * \\
(0.867)\end{array}$ & $\begin{array}{c}-4.385 * * * \\
(0.813)\end{array}$ & $\begin{array}{c}-3.200 * * * \\
(0.822)\end{array}$ & $\begin{array}{c}-3.511 * * * \\
(0.840)\end{array}$ & $\begin{array}{c}-3.326 * * * \\
(0.772)\end{array}$ & $\begin{array}{c}-3.131 * * * \\
(0.660)\end{array}$ \\
\hline Earning to assets & $\begin{array}{l}0.315^{* *} \\
(0.143)\end{array}$ & $\begin{array}{c}0.336 * * \\
(0.133)\end{array}$ & $\begin{array}{l}0.296 * * \\
(0.140)\end{array}$ & $\begin{array}{l}0.316^{* *} \\
(0.144)\end{array}$ & $\begin{array}{c}0.322 * * \\
(0.143)\end{array}$ & $\begin{array}{l}0.255^{*} \\
(0.136)\end{array}$ & $\begin{array}{l}0.301^{* *} \\
(0.142)\end{array}$ & $\begin{array}{c}0.375^{* *} \\
(0.146)\end{array}$ & $\begin{array}{l}0.270^{*} \\
(0.142)\end{array}$ & $\begin{array}{c}0.349 * * \\
(0.149)\end{array}$ & $\begin{array}{l}0.306^{* *} \\
(0.149)\end{array}$ & $\begin{array}{r}0.232 * * \\
(0.116)\end{array}$ \\
\hline Net loans to assets & $\begin{array}{l}-0.028 \\
(0.026)\end{array}$ & $\begin{array}{l}-0.026 \\
(0.025)\end{array}$ & $\begin{array}{l}-0.025 \\
(0.025)\end{array}$ & $\begin{array}{c}-0.03 \\
(0.027)\end{array}$ & $\begin{array}{l}-0.028 \\
(0.027)\end{array}$ & $\begin{array}{l}-0.033 \\
(0.027)\end{array}$ & $\begin{array}{c}-0.106^{* *} \\
(0.047)\end{array}$ & $\begin{array}{l}-0.087^{*} \\
(0.048)\end{array}$ & $\begin{array}{l}-0.094^{*} \\
(0.049)\end{array}$ & $\begin{array}{c}-0.105^{* *} \\
(0.049)\end{array}$ & $\begin{array}{c}-0.097 * * \\
(0.049)\end{array}$ & $\begin{array}{l}-0.079 * \\
(0.044)\end{array}$ \\
\hline $\begin{array}{l}\text { Liquid assets to deposits } \\
\text { and short term funding }\end{array}$ & $\begin{array}{l}0.027 * * \\
(0.011)\end{array}$ & $\begin{array}{l}0.025^{* *} \\
(0.011)\end{array}$ & $\begin{array}{l}0.027 * * \\
(0.011)\end{array}$ & $\begin{array}{l}0.028 * * \\
(0.011)\end{array}$ & $\begin{array}{l}0.026^{* *} \\
(0.011)\end{array}$ & $\begin{array}{l}0.026^{* *} \\
(0.011)\end{array}$ & $\begin{array}{l}0.026^{*} \\
(0.016)\end{array}$ & $\begin{array}{l}0.025^{*} \\
(0.015)\end{array}$ & $\begin{array}{c}0.026 \\
(0.016)\end{array}$ & $\begin{array}{c}0.025 \\
(0.016)\end{array}$ & $\begin{array}{c}0.024 \\
(0.015)\end{array}$ & $\begin{array}{l}0.029 * * \\
(0.014)\end{array}$ \\
\hline Fixed assets to assets & $\begin{array}{c}0.09 \\
(0.259)\end{array}$ & $\begin{array}{c}0.085 \\
(0.248)\end{array}$ & $\begin{array}{c}0.073 \\
(0.263)\end{array}$ & $\begin{array}{c}0.096 \\
(0.252)\end{array}$ & $\begin{array}{l}0.0710 \\
(0.254)\end{array}$ & $\begin{array}{c}0.051 \\
(0.280)\end{array}$ & $\begin{array}{l}0.026^{*} \\
(0.016)\end{array}$ & $\begin{array}{c}0.032 \\
(0.435)\end{array}$ & $\begin{array}{c}0.034 \\
(0.435)\end{array}$ & $\begin{array}{c}0.071 \\
(0.431)\end{array}$ & $\begin{array}{l}0.096 \\
(0.447)\end{array}$ & $\begin{array}{l}-0.233 \\
(0.354)\end{array}$ \\
\hline Size of government & $\begin{array}{l}-0.051 \\
(0.069)\end{array}$ & & & & & & $\begin{array}{l}0.0698 \\
(0.102)\end{array}$ & & & & & \\
\hline $\begin{array}{l}\text { Legal system and } \\
\text { property rights }\end{array}$ & & $\begin{array}{c}0.263 * * * \\
(0.075)\end{array}$ & & & & & & $\begin{array}{c}0.345 * * * \\
(0.0834)\end{array}$ & & & & \\
\hline Sound money & & & $\begin{array}{l}0.149 * * \\
(0.076)\end{array}$ & & & & & & $\begin{array}{c}0.162 * \\
(0.0852)\end{array}$ & & & \\
\hline $\begin{array}{l}\text { Freedom to trade } \\
\text { internationally }\end{array}$ & & & & $\begin{array}{c}0.277 * * * \\
(0.097)\end{array}$ & & & & & & $\begin{array}{c}0.444^{* * *} \\
(0.148)\end{array}$ & & \\
\hline Regulation & & & & & $\begin{array}{l}0.18^{* * *} \\
(0.062)\end{array}$ & & & & & & $\begin{array}{c}0.284^{* *} \\
(0.143)\end{array}$ & \\
\hline $\begin{array}{l}\text { Economic development } \\
\text { (II) }\end{array}$ & & & & & & $\begin{array}{c}0.497 * * * \\
(0.142)\end{array}$ & & & & & & $\begin{array}{l}0.77^{* * *} \\
(0.209)\end{array}$ \\
\hline GDP growth & & & & & & $\begin{array}{c}0.017 \\
(0.059)\end{array}$ & & & & & & $\begin{array}{l}-0.123 \\
(0.080)\end{array}$ \\
\hline Inflation & & & & & & $\begin{array}{l}-0.001 \\
(0.029)\end{array}$ & & & & & & $\begin{array}{l}-0.032 \\
(0.030)\end{array}$ \\
\hline Oil rent & & & & & & $\begin{array}{c}0.069 \\
(0.064)\end{array}$ & & & & & & $\begin{array}{l}0.144^{*} \\
(0.079)\end{array}$ \\
\hline Mineral rent & & & & & & $\begin{array}{c}0.021 \\
(0.089)\end{array}$ & & & & & & $\begin{array}{c}0.077 \\
(0.216)\end{array}$ \\
\hline Gas rent & & & & & & $\begin{array}{c}0.031 \\
(0.140)\end{array}$ & & & & & & $\begin{array}{c}-0.098 \\
(0.160)\end{array}$ \\
\hline Constant & $\begin{array}{c}62.24 * * * \\
(14.65)\end{array}$ & $\begin{array}{c}53.72 * * * \\
(12.08)\end{array}$ & $\begin{array}{c}49.87 * * * \\
(12.61)\end{array}$ & $\begin{array}{c}37.72 * * * \\
(13.56)\end{array}$ & $\begin{array}{c}46.97 * * * \\
(13.49)\end{array}$ & $\begin{array}{c}22.59 * * \\
(11.43)\end{array}$ & $\begin{array}{c}63.17 * * * \\
(17.27)\end{array}$ & $\begin{array}{c}67.03 * * * \\
(12.20)\end{array}$ & $\begin{array}{c}58.33 * * * \\
(13.05)\end{array}$ & $\begin{array}{c}44.25 * * * \\
(14.35)\end{array}$ & $\begin{array}{c}51.49 * * * \\
(16.94)\end{array}$ & $\begin{array}{c}13.42 \\
(12.51)\end{array}$ \\
\hline $\mathrm{N}$ & 764 & 764 & 764 & 764 & 764 & 755 & 427 & 427 & 428 & 427 & 427 & 418 \\
\hline Year dummy & Yes & Yes & Yes & Yes & Yes & No & Yes & Yes & Yes & Yes & Yes & No \\
\hline Chi2 & $0.00^{* * *}$ & $0.00 * * *$ & $0.00 * * *$ & $0.00^{* * *}$ & $0.00 * * *$ & $0.00 * * *$ & $0.00 * * *$ & $0.00^{* * *}$ & $0.00^{* * *}$ & $0.00^{* * *}$ & $0.00 * * *$ & $0.00^{* * *}$ \\
\hline R2 & 0.292 & 0.438 & 0.345 & 0.346 & 0.30 & 0.429 & 0.304 & 0.48 & 0.387 & 0.431 & 0.361 & 0.498 \\
\hline
\end{tabular}

Standard errors are clustered at the bank level and are reported in parentheses below their coefficient estimates.

* Statistical significance at the $10 \%$ level.

** Statistical significance at the $5 \%$ level.

*** Statistical significance at the $1 \%$ level. 
Table 6

The determinants of Islamic bank capital decisions: alternative capital ratios

\begin{tabular}{|c|c|c|c|c|c|c|c|c|}
\hline \multirow{2}{*}{$\begin{array}{l}\text { Variables } \\
\text { Model \# } \\
\end{array}$} & \multicolumn{4}{|c|}{ Total equity to assets } & \multicolumn{4}{|c|}{ Capital adequacy ratio } \\
\hline & [1] & [2] & [3] & [4] & [5] & [6] & [7] & [8] \\
\hline Logarithm total assets & $\begin{array}{l}-2.36 * * * \\
(0.707)\end{array}$ & $\begin{array}{c}-1.92 * * * \\
(0.544)\end{array}$ & $\begin{array}{c}-3.22 * * * \\
(0.843)\end{array}$ & $\begin{array}{c}-2.75^{* * *} \\
(0.638)\end{array}$ & $\begin{array}{c}-3.18 * * * \\
(0.920)\end{array}$ & $\begin{array}{l}-2.47 * * * \\
(0.688)\end{array}$ & $\begin{array}{c}-3.99 * * * \\
(0.994)\end{array}$ & $\begin{array}{c}-3.52 * * * \\
(0.851)\end{array}$ \\
\hline Earning to assets & $\begin{array}{c}0.342 * * \\
(0.137)\end{array}$ & $\begin{array}{l}0.28^{* *} \\
(0.140)\end{array}$ & $\begin{array}{c}0.306 * * \\
(0.136)\end{array}$ & $\begin{array}{l}0.247^{*} \\
(0.137)\end{array}$ & $\begin{array}{c}0.657 * * * \\
(0.239)\end{array}$ & $\begin{array}{l}0.538 * * \\
(0.210)\end{array}$ & $\begin{array}{c}0.576^{* *} \\
(0.258)\end{array}$ & $\begin{array}{l}0.465^{* *} \\
(0.227)\end{array}$ \\
\hline Net loans to assets & $\begin{array}{l}-0.009 \\
(0.030)\end{array}$ & $\begin{array}{l}-0.015 \\
(0.031)\end{array}$ & $\begin{array}{l}-0.027 \\
(0.027)\end{array}$ & $\begin{array}{l}-0.032 \\
(0.028)\end{array}$ & $\begin{array}{l}-0.099 \\
(0.063)\end{array}$ & $\begin{array}{l}-0.104 \\
(0.066)\end{array}$ & $\begin{array}{l}-0.119^{*} \\
(0.063)\end{array}$ & $\begin{array}{l}-0.13^{* *} \\
(0.065)\end{array}$ \\
\hline $\begin{array}{l}\text { Liquid assets to deposits and short term } \\
\text { funding }\end{array}$ & $\begin{array}{c}0.040 * * * \\
(0.013)\end{array}$ & $\begin{array}{c}0.041^{* * *} \\
(0.013)\end{array}$ & $\begin{array}{l}0.026^{* *} \\
(0.011)\end{array}$ & $\begin{array}{l}0.026^{* *} \\
(0.011)\end{array}$ & $\begin{array}{c}0.044 * * * \\
(0.017)\end{array}$ & $\begin{array}{c}0.052^{* * *} \\
(0.018)\end{array}$ & $\begin{array}{c}0.039 * * \\
(0.019)\end{array}$ & $\begin{array}{c}0.044^{* *} \\
(0.021)\end{array}$ \\
\hline Fixed assets to assets & $\begin{array}{c}0.28 \\
(0.223)\end{array}$ & $\begin{array}{c}0.26 \\
(0.241)\end{array}$ & $\begin{array}{c}0.091 \\
(0.243)\end{array}$ & $\begin{array}{c}0.061 \\
(0.271)\end{array}$ & $\begin{array}{c}0.592 \\
(0.588)\end{array}$ & $\begin{array}{c}0.276 \\
(0.582)\end{array}$ & $\begin{array}{c}0.328 \\
(0.595)\end{array}$ & $\begin{array}{c}0.143 \\
(0.631)\end{array}$ \\
\hline Economic development (I) & $\begin{array}{c}0.302 * * * \\
(0.112)\end{array}$ & $\begin{array}{c}0.286 * * * \\
(0.108)\end{array}$ & & & $\begin{array}{c}0.514 * * * \\
(0.157)\end{array}$ & $\begin{array}{c}0.436 * * * \\
(0.168)\end{array}$ & & \\
\hline Economic development (II) & & & $\begin{array}{c}0.531 * * * \\
(0.145)\end{array}$ & $\begin{array}{c}0.493 * * * \\
(0.146)\end{array}$ & & & $\begin{array}{c}0.825 * * * \\
(0.226)\end{array}$ & $\begin{array}{c}0.712 * * * \\
(0.209)\end{array}$ \\
\hline Constant & $\begin{array}{c}30.33^{* * *} \\
(11.51)\end{array}$ & $\begin{array}{c}23.59 * * * \\
(8.242)\end{array}$ & $\begin{array}{l}27.66^{*} \\
(14.34)\end{array}$ & $\begin{array}{l}21.80^{*} \\
(11.46)\end{array}$ & $\begin{array}{l}36.69 * \\
(19.86)\end{array}$ & $\begin{array}{c}30.03 * * * \\
(11.36)\end{array}$ & $\begin{array}{c}25.00 \\
(22.21)\end{array}$ & $\begin{array}{c}26.24 \\
(16.11)\end{array}$ \\
\hline $\mathrm{N}$ & 862 & 851 & 764 & 755 & 529 & 520 & 481 & 472 \\
\hline Year dummy & Yes & No & Yes & No & Yes & No & Yes & No \\
\hline Macroeconomics & No & Yes & No & Yes & No & Yes & No & Yes \\
\hline Chi2 & $0.00^{* * *}$ & $0.00 * * *$ & $0.00 * * *$ & $0.00 * * *$ & $0.00 * * *$ & $0.00 * * *$ & $0.00 * * *$ & $0.00^{* * *}$ \\
\hline R2 & 0.384 & 0.442 & 0.378 & 0.438 & 0.441 & 0.45 & 0.46 & 0.479 \\
\hline
\end{tabular}

Standard errors are clustered at the bank level and are reported in parentheses below their coefficient estimates.

* Statistical significance at the $10 \%$ level.

** Statistical significance at the $5 \%$ level.

*** Statistical significance at the $1 \%$ level. 
Table 7

The determinants of Islamic bank capital decisions: highly capitalized banks

\begin{tabular}{|c|c|c|c|c|c|c|}
\hline \multirow{3}{*}{$\begin{array}{l}\text { Variables } \\
\text { Model \# }\end{array}$} & \multicolumn{6}{|c|}{ Common equity to assets $>$ Q3 } \\
\hline & \multicolumn{2}{|c|}{$\begin{array}{c}\mathrm{GLS}(\text { Cap }>Q 3)=1 \\
\text { otherwise } 0\end{array}$} & \multicolumn{2}{|c|}{$\begin{array}{c}\text { Logit }(\text { Cap }>Q 3)=1 \\
\text { otherwise 0 }\end{array}$} & \multicolumn{2}{|c|}{$\begin{array}{c}\text { Probit }(\text { Cap }>Q 3)=1 \\
\text { otherwise 0 }\end{array}$} \\
\hline & [1] & [2] & [3] & [4] & [5] & [6] \\
\hline Logarithm total assets & $\begin{array}{c}-0.047 * * * \\
(0.015)\end{array}$ & $\begin{array}{l}-0.059^{* * * *} \\
(0.012)\end{array}$ & $\begin{array}{c}-0.499 * * \\
(0.232)\end{array}$ & $\begin{array}{c}-0.568 * * * \\
(0.194)\end{array}$ & $\begin{array}{c}-0.247 * * \\
(0.100)\end{array}$ & $\begin{array}{c}-0.308^{* * *} \\
(0.0865)\end{array}$ \\
\hline Earning to assets & $\begin{array}{c}0.012 * * * \\
(0.004)\end{array}$ & $\begin{array}{l}0.012 * * * \\
(0.004)\end{array}$ & $\begin{array}{c}0.144 * * * \\
(0.051)\end{array}$ & $\begin{array}{l}0.107^{* *} \\
(0.045)\end{array}$ & $\begin{array}{c}0.076 * * * \\
(0.023)\end{array}$ & $\begin{array}{c}0.058^{* * *} \\
(0.022)\end{array}$ \\
\hline Net loans to assets & $\begin{array}{l}-0.000 \\
(0.001)\end{array}$ & $\begin{array}{l}-0.001 \\
(0.001)\end{array}$ & $\begin{array}{c}0.004 \\
(0.009)\end{array}$ & $\begin{array}{c}0.004 \\
(0.010)\end{array}$ & $\begin{array}{c}0.001 \\
(0.002)\end{array}$ & $\begin{array}{c}0.002 \\
(0.005)\end{array}$ \\
\hline $\begin{array}{l}\text { Liquid assets to deposits } \\
\text { and short term funding }\end{array}$ & $\begin{array}{l}0.001^{*} \\
(0.000)\end{array}$ & $\begin{array}{c}0.001 * * \\
(0.000)\end{array}$ & $\begin{array}{l}0.009 * * \\
(0.003)\end{array}$ & $\begin{array}{l}0.009 * * \\
(0.004)\end{array}$ & $\begin{array}{c}0.005^{* * *} \\
(0.001)\end{array}$ & $\begin{array}{c}0.005 * * * \\
(0.001)\end{array}$ \\
\hline Fixed assets to assets & $\begin{array}{c}0.017^{* * * *} \\
(0.006)\end{array}$ & $\begin{array}{l}0.016^{* *} \\
(0.006)\end{array}$ & $\begin{array}{l}0.141^{* *} \\
(0.067)\end{array}$ & $\begin{array}{l}0.108 * \\
(0.065)\end{array}$ & $\begin{array}{l}0.081^{* *} \\
(0.035)\end{array}$ & $\begin{array}{l}0.062 * \\
(0.035)\end{array}$ \\
\hline Economic development & $\begin{array}{c}0.009^{* * * *} \\
(0.003)\end{array}$ & $\begin{array}{c}0.008^{* * *} \\
(0.003)\end{array}$ & $\begin{array}{c}0.064 \\
(0.042)\end{array}$ & $\begin{array}{l}0.068^{*} \\
(0.041)\end{array}$ & $\begin{array}{c}0.031 \\
(0.019)\end{array}$ & $\begin{array}{l}0.035^{*} \\
(0.019)\end{array}$ \\
\hline Constant & $\begin{array}{c}0.215 \\
(0.289)\end{array}$ & $\begin{array}{l}0.418^{*} \\
(0.216)\end{array}$ & $\begin{array}{l}-0.275 \\
(2.155)\end{array}$ & $\begin{array}{c}0.270 \\
(1.957)\end{array}$ & $\begin{array}{l}-0.259 \\
(1.140)\end{array}$ & $\begin{array}{c}0.199 \\
(1.097)\end{array}$ \\
\hline $\mathrm{N}$ & 862 & 851 & 862 & 851 & 862 & 851 \\
\hline Year dummy & Yes & No & Yes & No & Yes & No \\
\hline Macroeconomics & No & Yes & No & Yes & No & Yes \\
\hline Chi2 & $0.00 * * *$ & $0.00 * * *$ & $0.00 * * *$ & $0.00 * * *$ & $0.00 * * *$ & $0.00 * * *$ \\
\hline R2/Pseudo R2 & 0.219 & 0.222 & 0.252 & 0.271 & 0.245 & 0.27 \\
\hline \multirow[t]{2}{*}{ Variables } & \multicolumn{6}{|c|}{ Total equity to assets } \\
\hline & \multicolumn{2}{|c|}{$\begin{array}{c}\text { GLS }(\text { Cap }>\text { Q3) }=1 \\
\text { otherwise } 0\end{array}$} & \multicolumn{2}{|c|}{$\begin{array}{c}\text { Logit }(\text { Cap }>Q 3)=1 \\
\text { otherwise 0 }\end{array}$} & \multicolumn{2}{|c|}{$\begin{array}{c}\text { Probit }(\text { Cap }>Q 3)=1 \\
\text { otherwise 0 }\end{array}$} \\
\hline Model \# & [1] & [2] & [3] & [4] & [5] & [6] \\
\hline Logarithm total assets & $\begin{array}{c}-0.0428^{* * *} \\
(0.0141)\end{array}$ & $\begin{array}{c}-0.0577 * * * \\
(0.0119)\end{array}$ & $\begin{array}{c}-0.461^{* *} \\
(0.228)\end{array}$ & $\begin{array}{c}-0.562 * * * \\
(0.195)\end{array}$ & $\begin{array}{c}-0.227 * * \\
(0.097)\end{array}$ & $\begin{array}{c}-0.305^{* * * *} \\
(0.085)\end{array}$ \\
\hline Earning to assets & $\begin{array}{l}0.011^{* *} \\
(0.004)\end{array}$ & $\begin{array}{l}0.011^{* * * *} \\
(0.004)\end{array}$ & $\begin{array}{c}0.128^{* * *} \\
(0.049)\end{array}$ & $\begin{array}{l}0.105^{* *} \\
(0.045)\end{array}$ & $\begin{array}{c}0.068^{* * *} \\
(0.022)\end{array}$ & $\begin{array}{c}0.056^{* * *} \\
(0.021)\end{array}$ \\
\hline Net loans to assets & $\begin{array}{l}-0.000 \\
(0.001)\end{array}$ & $\begin{array}{l}-0.000 \\
(0.001)\end{array}$ & $\begin{array}{c}0.001 \\
(0.008)\end{array}$ & $\begin{array}{c}0.002 \\
(0.009)\end{array}$ & $\begin{array}{l}-0.001 \\
(0.005)\end{array}$ & $\begin{array}{c}0.000 \\
(0.005)\end{array}$ \\
\hline $\begin{array}{l}\text { Liquid assets to deposits } \\
\text { and short term funding }\end{array}$ & $\begin{array}{l}0.000^{*} \\
(0.000)\end{array}$ & $\begin{array}{l}0.001^{*} \\
(0.000)\end{array}$ & $\begin{array}{c}0.007 * * * \\
(0.003)\end{array}$ & $\begin{array}{c}0.008^{* *} \\
(0.003)\end{array}$ & $\begin{array}{c}0.004^{* * *} \\
(0.001)\end{array}$ & $\begin{array}{c}0.004^{* * *} \\
(0.001)\end{array}$ \\
\hline Fixed assets to assets & $\begin{array}{l}0.015^{* *} \\
(0.006)\end{array}$ & $\begin{array}{l}0.014^{* *} \\
(0.006)\end{array}$ & $\begin{array}{l}0.124 * * \\
(0.059)\end{array}$ & $\begin{array}{c}0.093 \\
(0.060)\end{array}$ & $\begin{array}{l}0.072 * * \\
(0.033)\end{array}$ & $\begin{array}{c}0.054 \\
(0.033)\end{array}$ \\
\hline Economic development & $\begin{array}{l}0.009^{* * * *} \\
(0.003)\end{array}$ & $\begin{array}{l}0.009^{* * * *} \\
(0.003)\end{array}$ & $\begin{array}{c}0.061 \\
(0.043)\end{array}$ & $\begin{array}{c}0.063 \\
(0.041)\end{array}$ & $\begin{array}{c}0.029 \\
(0.019)\end{array}$ & $\begin{array}{l}0.032^{*} \\
(0.019)\end{array}$ \\
\hline Constant & $\begin{array}{c}0.149 \\
(0.280)\end{array}$ & $\begin{array}{l}0.416^{*} \\
(0.216)\end{array}$ & $\begin{array}{l}-0.443 \\
(1.992)\end{array}$ & $\begin{array}{c}0.779 \\
(1.839)\end{array}$ & $\begin{array}{c}-0.330 \\
(1.068)\end{array}$ & $\begin{array}{c}0.452 \\
(1.039)\end{array}$ \\
\hline $\mathrm{N}$ & 862 & 851 & 862 & 851 & 862 & 851 \\
\hline Year dummy & Yes & No & Yes & No & Yes & No \\
\hline Macroeconomics & No & Yes & No & Yes & No & Yes \\
\hline Chi2 & $0.00^{* * *}$ & $0.00^{* * *}$ & $0.00 * * *$ & $0.00^{* * *}$ & $0.00 * * *$ & $0.00 * * *$ \\
\hline R2 & 0.202 & 0.194 & 0.235 & 0.256 & 0.229 & 0.256 \\
\hline
\end{tabular}

\begin{tabular}{cccccc}
\multicolumn{2}{c}{ Tier 1 capital to risk weighted assets } \\
\hline \multicolumn{2}{c}{ GLS(Cap $>$ Q3) $=1$} & \multicolumn{2}{c}{$\begin{array}{l}\text { Logit (Cap }>Q 3)=1 \\
\text { otherwise 0 }\end{array}$} & \multicolumn{2}{c}{$\begin{array}{c}\text { Probit (Cap }>Q 3)=1 \\
\text { otherwise 0 }\end{array}$} \\
\hline otherwise 0 & {$[8]$} & {$[9]$} & {$[10]$} & {$[11]$} & {$[12]$} \\
\hline$-0.105^{* * *}$ & $-0.097^{* * *}$ & $-0.855^{* * *}$ & $-1.079^{* * *}$ & $-0.455^{* * *}$ & $-0.599^{* * *}$ \\
$(0.023)$ & $(0.021)$ & $(0.246)$ & $(0.258)$ & $(0.129)$ & $(0.140)$ \\
$0.014^{* *}$ & $0.011^{* *}$ & $0.185^{* *}$ & $0.137^{* *}$ & $0.098^{* * *}$ & $0.074^{* *}$ \\
$(0.006)$ & $(0.005)$ & $(0.086)$ & $(0.061)$ & $(0.037)$ & $(0.030)$ \\
-0.002 & -0.002 & -0.017 & -0.006 & -0.009 & -0.009 \\
$(0.001)$ & $(0.001)$ & $(0.013)$ & $(0.014)$ & $(0.007)$ & $(0.007)$ \\
-0.001 & -0.000 & 0.002 & 0.001 & 0.001 & 0.001 \\
$(0.000)$ & $(0.000)$ & $(0.003)$ & $(0.002)$ & $(0.001)$ & $(0.001)$ \\
0.02 & 0.014 & $0.392^{*}$ & 0.286 & $0.198^{* *}$ & $0.146^{*}$ \\
$(0.014)$ & $(0.013)$ & $(0.210)$ & $(0.196)$ & $(0.084)$ & $(0.083)$ \\
$0.014^{* * *}$ & $0.012^{* * *}$ & $0.111^{* * *}$ & $0.172^{* * *}$ & $0.0613^{* * *}$ & $0.095^{* * *}$ \\
$(0.004)$ & $(0.004)$ & $(0.038)$ & $(0.039)$ & $(0.020)$ & $(0.022)$ \\
$0.88^{* *}$ & $0.80^{* * *}$ & 3.248 & 1.122 & 1.538 & 0.643 \\
$(0.424)$ & $(0.303)$ & $(4.257)$ & $(3.790)$ & $(2.204)$ & $(2.023)$ \\
472 & 463 & 442 & 463 & 442 & 463 \\
Yes & No & Yes & No & Yes & No \\
No & Yes & No & Yes & No & Yes \\
$0.00^{* * *}$ & $0.00^{* * *}$ & $0.00^{* * *}$ & $0.00^{* * *}$ & $0.00^{* * *}$ & $0.00^{* * *}$ \\
0.266 & 0.278 & 0.323 & 0.387 & 0.326 & 0.395 \\
\hline
\end{tabular}

\begin{tabular}{|c|c|c|c|c|c|}
\hline \multicolumn{6}{|c|}{ Capital adequacy ratio } \\
\hline \multicolumn{2}{|c|}{$\begin{array}{c}\mathrm{GLS}(\text { Cap }>\text { Q3) } \\
\text { otherwise } 0\end{array}$} & \multicolumn{2}{|c|}{$\begin{array}{c}\text { Logit }(\text { Cap }>Q 3)=1 \\
\text { otherwise 0 }\end{array}$} & \multicolumn{2}{|c|}{$\begin{array}{c}\text { Probit }(\text { Cap }>Q 3)=1 \\
\text { otherwise 0 }\end{array}$} \\
\hline [7] & [8] & [9] & [10] & [11] & [12] \\
\hline$-0.087 * * *$ & $-0.086 * * *$ & $-0.817^{* * *}$ & $-0.935^{* * *}$ & $-0.418^{* * *}$ & $-0.479 * * *$ \\
\hline$(0.022)$ & $(0.019)$ & $(0.227)$ & $(0.243)$ & $(0.122)$ & $(0.126)$ \\
\hline $0.017 * * *$ & $0.014^{* *}$ & $0.209^{* *}$ & $0.17 * *$ & $0.107^{* * *}$ & $0.087 * * *$ \\
\hline$(0.006)$ & $(0.006)$ & $(0.082)$ & $(0.070)$ & $(0.036)$ & $(0.033)$ \\
\hline$-0.003 * *$ & $-0.003 * *$ & -0.016 & -0.012 & -0.009 & -0.007 \\
\hline$(0.001)$ & $(0.001)$ & $(0.011)$ & $(0.011)$ & $(0.006)$ & $(0.006)$ \\
\hline 0.000 & 0.000 & $0.005^{*}$ & 0.004 & $0.003 * *$ & $0.003^{*}$ \\
\hline$(0.000)$ & $(0.000)$ & $(0.003)$ & $(0.003)$ & $(0.001)$ & $(0.001)$ \\
\hline 0.019 & 0.013 & $0.363^{*}$ & 0.286 & $0.176^{* *}$ & $0.141 *$ \\
\hline$(0.014)$ & $(0.014)$ & $(0.202)$ & $(0.191)$ & $(0.079)$ & $(0.079)$ \\
\hline $0.012 * * *$ & $0.011^{* * *}$ & $0.103^{* * *}$ & $0.149 * * *$ & $0.053^{* * *}$ & $0.075^{* * *}$ \\
\hline$(0.004)$ & $(0.004)$ & $(0.036)$ & $(0.040)$ & $(0.019)$ & $(0.023)$ \\
\hline $0.791 * *$ & $0.741^{* * *}$ & 2.682 & 0.741 & 1.312 & 0.338 \\
\hline$(0.400)$ & $(0.286)$ & (3.757) & (3.294) & $(1.932)$ & (1.711) \\
\hline 529 & 520 & 529 & 520 & 529 & 520 \\
\hline Yes & No & Yes & No & Yes & No \\
\hline No & Yes & No & Yes & No & Yes \\
\hline $0.00 * * *$ & $0.00^{* * *}$ & $0.00^{* * *}$ & $0.00^{* * *}$ & $0.00^{* * *}$ & $0.00^{* * *}$ \\
\hline 0.312 & 0.303 & 0.359 & 0.391 & 0.356 & 0.388 \\
\hline
\end{tabular}

* Statistical significance at the $10 \%$ lev

*** Statistical significance at the $1 \%$ level. 
Table 8

The determinants of Islamic bank capital decisions: minimally capitalized banks

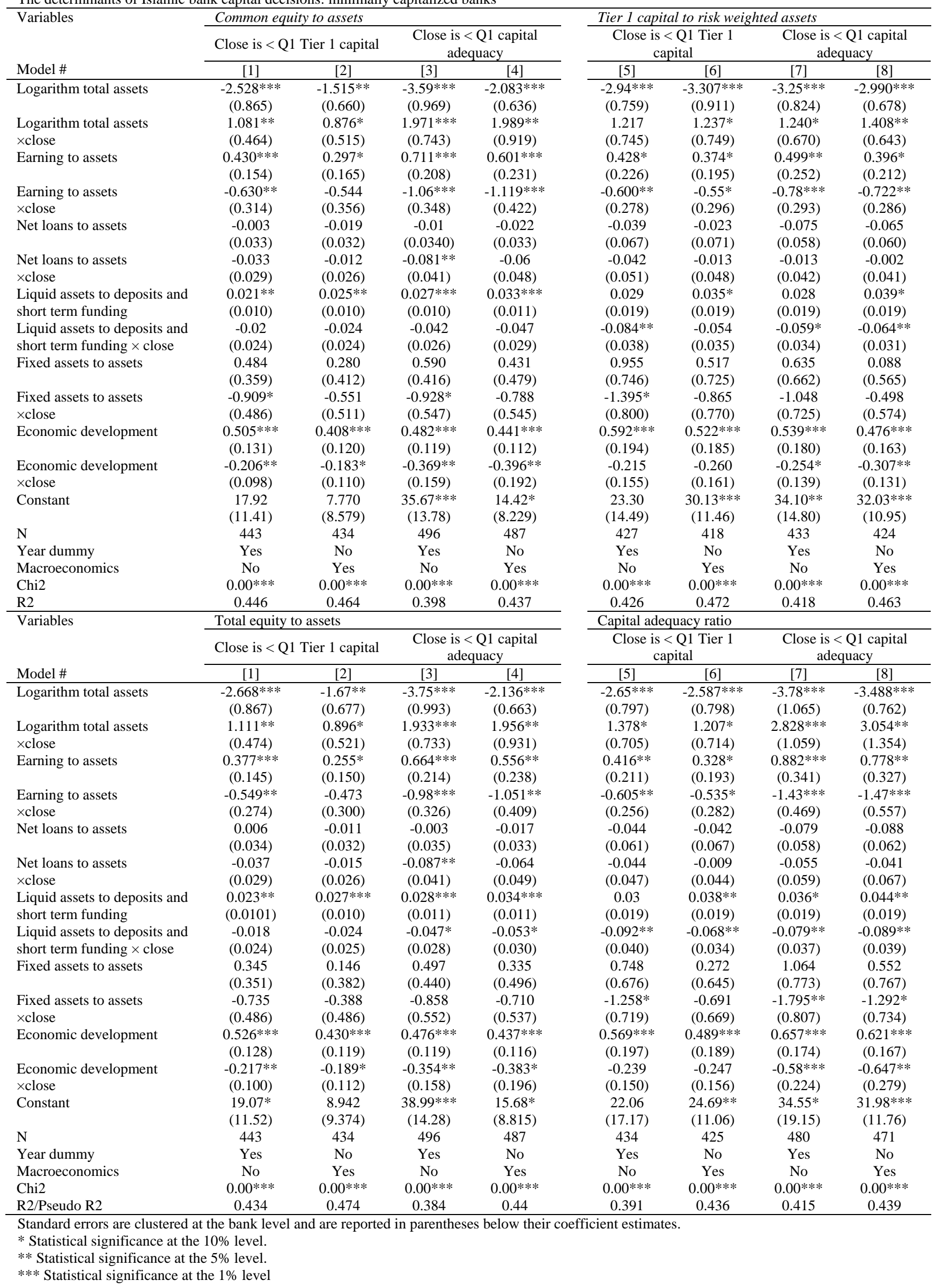


Table 9

The determinants of Islamic bank capital decisions: first difference regression

\begin{tabular}{|c|c|c|c|c|c|c|c|c|}
\hline \multirow{2}{*}{$\begin{array}{l}\text { Variables } \\
\text { Model \# }\end{array}$} & \multicolumn{2}{|c|}{$\Delta$ Common equity to assets } & \multicolumn{2}{|c|}{$\begin{array}{l}\Delta \text { Tier } 1 \text { capital to risk } \\
\text { weighted assets }\end{array}$} & \multicolumn{2}{|c|}{$\Delta$ Total equity to assets } & \multicolumn{2}{|c|}{$\Delta$ Capital adequacy ratio } \\
\hline & [1] & [2] & [3] & [4] & [5] & [6] & [7] & [8] \\
\hline$\Delta$ Size & $\begin{array}{c}-3.817 * * * \\
(1.114)\end{array}$ & $\begin{array}{c}-3.479 * * * \\
(1.139)\end{array}$ & $\begin{array}{c}-2.418^{* *} \\
(0.970)\end{array}$ & $\begin{array}{l}-1.678^{*} \\
(0.939)\end{array}$ & $\begin{array}{c}-3.699 * * * \\
(1.106)\end{array}$ & $\begin{array}{c}-3.344^{* * *} \\
(1.133)\end{array}$ & $\begin{array}{c}-2.502 * * * \\
(0.922)\end{array}$ & $\begin{array}{l}-1.600^{*} \\
(0.857)\end{array}$ \\
\hline$\Delta$ Earning to assets & $\begin{array}{c}0.599 \\
(0.366)\end{array}$ & $\begin{array}{c}0.487 \\
(0.366)\end{array}$ & $\begin{array}{c}0.837 * * * \\
(0.283)\end{array}$ & $\begin{array}{c}0.62 * \\
(0.337)\end{array}$ & $\begin{array}{l}0.605^{*} \\
(0.346)\end{array}$ & $\begin{array}{c}0.482 \\
(0.343)\end{array}$ & $\begin{array}{c}0.786 * * * \\
(0.266)\end{array}$ & $\begin{array}{c}0.6^{*} \\
(0.338)\end{array}$ \\
\hline$\Delta$ Net loans to assets & $\begin{array}{l}-0.089 \\
(0.069)\end{array}$ & $\begin{array}{l}-0.088 \\
(0.068)\end{array}$ & $\begin{array}{l}-0.067 \\
(0.070)\end{array}$ & $\begin{array}{l}-0.042 \\
(0.073)\end{array}$ & $\begin{array}{l}-0.086 \\
(0.069)\end{array}$ & $\begin{array}{l}-0.087 \\
(0.069)\end{array}$ & $\begin{array}{c}-0.145 * * \\
(0.071)\end{array}$ & $\begin{array}{l}-0.103 \\
(0.065)\end{array}$ \\
\hline $\begin{array}{l}\Delta \text { Liquid assets to deposits and } \\
\text { short term funding }\end{array}$ & $\begin{array}{c}0.05^{*} \\
(0.027)\end{array}$ & $\begin{array}{l}0.053^{* *} \\
(0.027)\end{array}$ & $\begin{array}{c}0.064^{* *} \\
(0.026)\end{array}$ & $\begin{array}{c}0.096 * * * \\
(0.021)\end{array}$ & $\begin{array}{l}0.057 * * \\
(0.027)\end{array}$ & $\begin{array}{l}0.059 * * \\
(0.027)\end{array}$ & $\begin{array}{l}0.066 * * \\
(0.031)\end{array}$ & $\begin{array}{c}0.101^{* * *} \\
(0.022)\end{array}$ \\
\hline$\Delta$ Fixed assets to assets & $\begin{array}{l}1.094 * * * \\
(0.413)\end{array}$ & $\begin{array}{l}1.112^{* * *} \\
(0.406)\end{array}$ & $\begin{array}{l}2.265^{* *} \\
(0.925)\end{array}$ & $\begin{array}{l}1.733^{* *} \\
(0.807)\end{array}$ & $\begin{array}{l}1.096 * * * \\
(0.404)\end{array}$ & $\begin{array}{c}1.103 * * * \\
(0.401)\end{array}$ & $\begin{array}{l}2.387 * * * \\
(0.800)\end{array}$ & $\begin{array}{c}1.926 * * * \\
(0.710)\end{array}$ \\
\hline$\Delta$ Economic development & $\begin{array}{c}-0.103 \\
(0.164)\end{array}$ & $\begin{array}{l}-0.118 \\
(0.182)\end{array}$ & $\begin{array}{l}-0.205 \\
(0.159)\end{array}$ & $\begin{array}{l}-0.503^{* *} \\
(0.227)\end{array}$ & $\begin{array}{c}-0.082 \\
(0.161)\end{array}$ & $\begin{array}{l}-0.117 \\
(0.177)\end{array}$ & $\begin{array}{c}-0.19 \\
(0.167)\end{array}$ & $\begin{array}{c}-0.43^{* *} \\
(0.209)\end{array}$ \\
\hline$\Delta$ GDP growth & & $\begin{array}{c}0.594 * * * \\
(0.190)\end{array}$ & & $\begin{array}{c}0.145 \\
(0.178)\end{array}$ & & $\begin{array}{c}0.596 * * * \\
(0.191)\end{array}$ & & $\begin{array}{l}0.368^{*} \\
(0.217)\end{array}$ \\
\hline$\Delta$ Inflation & & $\begin{array}{c}-0.203^{* *} \\
(0.089)\end{array}$ & & $\begin{array}{l}-0.005 \\
(0.084)\end{array}$ & & $\begin{array}{c}-0.202^{* *} \\
(0.089)\end{array}$ & & $\begin{array}{l}-0.057 \\
(0.084)\end{array}$ \\
\hline$\Delta$ Oil rent & & $\begin{array}{l}-0.266 \\
(0.229)\end{array}$ & & $\begin{array}{c}-0.721^{* *} \\
(0.327)\end{array}$ & & $\begin{array}{l}-0.313 \\
(0.231)\end{array}$ & & $\begin{array}{l}-0.333^{*} \\
(0.187)\end{array}$ \\
\hline$\Delta$ Mineral rent & & $\begin{array}{l}-0.147 \\
(0.151)\end{array}$ & & $\begin{array}{c}-0.97 * * * \\
(0.355)\end{array}$ & & $\begin{array}{l}-0.150 \\
(0.148)\end{array}$ & & $\begin{array}{c}-2.325^{* *} \\
(0.957)\end{array}$ \\
\hline$\Delta$ Gas rent & & $\begin{array}{c}0.345 \\
(0.234)\end{array}$ & & $\begin{array}{l}-0.146 \\
(0.321)\end{array}$ & & $\begin{array}{c}0.269 \\
(0.240)\end{array}$ & & $\begin{array}{l}-0.127 \\
(0.276)\end{array}$ \\
\hline Constant & $\begin{array}{c}-0.038 \\
(0.074)\end{array}$ & $\begin{array}{c}0.005 \\
(0.063)\end{array}$ & $\begin{array}{c}-0.12 \\
(0.159)\end{array}$ & $\begin{array}{c}-0.175 \\
(0.155)\end{array}$ & $\begin{array}{c}-0.056 \\
(0.077)\end{array}$ & $\begin{array}{c}-0.027 \\
(0.065)\end{array}$ & $\begin{array}{l}-0.094 \\
(0.146)\end{array}$ & $\begin{array}{l}-0.162 \\
(0.144)\end{array}$ \\
\hline $\mathrm{N}$ & 834 & 812 & 418 & 399 & 835 & 813 & 470 & 450 \\
\hline Year dummy & No & No & No & No & No & No & No & No \\
\hline Chi2 & $0.00^{* * *}$ & $0.00^{* * *}$ & $0.00 * * *$ & $0.00 * * *$ & $0.00 * * *$ & $0.00^{* * *}$ & $0.00 * * *$ & $0.00^{* * *}$ \\
\hline $\mathrm{R} 2$ & 0.344 & 0.4 & 0.38 & 0.464 & 0.44 & 0.401 & 0.417 & 0.511 \\
\hline
\end{tabular}

Standard errors are clustered at the bank level and are reported in parentheses below their coefficient estimates.

* Statistical significance at the $10 \%$ level.

** Statistical significance at the $5 \%$ level.

*** Statistical significance at the $1 \%$ level. 
Table 10

The determinants of Islamic bank capital decisions: Legal and political systems

\begin{tabular}{|c|c|c|c|c|c|c|c|c|c|c|}
\hline \multirow[t]{2}{*}{ Variables } & \multicolumn{5}{|c|}{ Common equity to total assets } & \multicolumn{5}{|c|}{ Tier 1 capital to risk weighted assets } \\
\hline & GCC & Developing & $\begin{array}{c}\text { Western } \\
\text { legal } \\
\text { system } \\
\end{array}$ & $\begin{array}{c}\text { Hybrid } \\
\text { legal } \\
\text { system } \\
\end{array}$ & $\begin{array}{c}\text { Sharia'a } \\
\text { legal } \\
\text { system } \\
\end{array}$ & GCC & Developing & $\begin{array}{c}\text { Western } \\
\text { legal } \\
\text { system } \\
\end{array}$ & $\begin{array}{c}\text { Hybrid } \\
\text { legal } \\
\text { system } \\
\end{array}$ & $\begin{array}{c}\text { Sharia'a } \\
\text { legal } \\
\text { system } \\
\end{array}$ \\
\hline Model \# & [1] & [2] & [3] & [4] & [5] & [6] & [7] & [8] & [9] & [10] \\
\hline Logarithm total assets & $\begin{array}{l}-6.72 * * * \\
(1.606)\end{array}$ & $\begin{array}{l}-1.984 * * * \\
(0.634)\end{array}$ & $\begin{array}{c}-4.284^{* *} \\
(2.126)\end{array}$ & $\begin{array}{c}-2.77 * * * \\
(0.714)\end{array}$ & $\begin{array}{c}-4.421^{* * *} \\
(1.228)\end{array}$ & $\begin{array}{l}-4.11^{* * *} \\
(1.301)\end{array}$ & $\begin{array}{l}-3.119 * * * \\
(0.735)\end{array}$ & $\begin{array}{l}-4.259 \\
(3.212)\end{array}$ & $\begin{array}{c}-3.926 * * * \\
(0.735)\end{array}$ & $\begin{array}{c}0.789 \\
(2.848)\end{array}$ \\
\hline Earning to assets & $\begin{array}{c}0.388^{* *} \\
(0.166)\end{array}$ & $\begin{array}{c}0.449 * * * \\
(0.149)\end{array}$ & $\begin{array}{l}0.0363 \\
(0.403)\end{array}$ & $\begin{array}{c}0.402 * * * \\
(0.139)\end{array}$ & $\begin{array}{c}0.617 * * \\
(0.308)\end{array}$ & $\begin{array}{l}0.427 * * \\
(0.198)\end{array}$ & $\begin{array}{c}0.519 * * * \\
(0.185)\end{array}$ & $\begin{array}{l}-1.588 \\
(1.165)\end{array}$ & $\begin{array}{c}0.452 * * * \\
(0.148)\end{array}$ & $\begin{array}{l}-0.244 \\
(0.487)\end{array}$ \\
\hline Net loans to assets & $\begin{array}{l}-0.054 \\
(0.047)\end{array}$ & $\begin{array}{l}-0.011 \\
(0.030)\end{array}$ & $\begin{array}{l}-0.075 \\
(0.140)\end{array}$ & $\begin{array}{l}-0.004 \\
(0.026)\end{array}$ & $\begin{array}{l}-0.019 \\
(0.041)\end{array}$ & $\begin{array}{c}0.009 \\
(0.099)\end{array}$ & $\begin{array}{l}-0.053 \\
(0.055)\end{array}$ & $\begin{array}{c}0.313 \\
(0.192)\end{array}$ & $\begin{array}{c}-0.096^{* *} \\
(0.049)\end{array}$ & $\begin{array}{l}-0.036 \\
(0.122)\end{array}$ \\
\hline $\begin{array}{l}\text { Liquid assets to deposits } \\
\text { and short term funding }\end{array}$ & $\begin{array}{c}0.049 * * * \\
(0.016)\end{array}$ & $\begin{array}{c}0.043 * * * \\
(0.015)\end{array}$ & $\begin{array}{l}0.054^{*} \\
(0.026)\end{array}$ & $\begin{array}{l}0.031^{* *} \\
(0.014)\end{array}$ & $\begin{array}{c}0.053^{* * * *} \\
(0.007)\end{array}$ & $\begin{array}{l}0.058^{* *} \\
(0.025)\end{array}$ & $\begin{array}{l}0.033^{* *} \\
(0.016)\end{array}$ & $\begin{array}{l}0.048^{*} \\
(0.026)\end{array}$ & $\begin{array}{l}0.028 \\
(0.018)\end{array}$ & $\begin{array}{l}0.08 * * * \\
(0.023)\end{array}$ \\
\hline Fixed assets to assets & $\begin{array}{l}-0.302 \\
(0.403)\end{array}$ & $\begin{array}{l}0.298 \\
(0.234)\end{array}$ & $\begin{array}{c}1.264 * * * \\
(0.177)\end{array}$ & $\begin{array}{c}0.241 \\
(0.268)\end{array}$ & $\begin{array}{l}-0.243 \\
(0.334)\end{array}$ & $\begin{array}{c}0.432 \\
(0.663)\end{array}$ & $\begin{array}{c}0.465 \\
(0.529)\end{array}$ & $\begin{array}{l}1.775 \\
(2.619)\end{array}$ & $\begin{array}{l}-0.092 \\
(0.396)\end{array}$ & $\begin{array}{l}5.389 * * \\
(2.229)\end{array}$ \\
\hline Economic development & $\begin{array}{c}0.442 \\
(0.273)\end{array}$ & $\begin{array}{l}0.258 * * \\
(0.109)\end{array}$ & $\begin{array}{c}0.702 \\
(0.431)\end{array}$ & $\begin{array}{c}0.619 * * * \\
(0.117)\end{array}$ & $\begin{array}{l}-0.015 \\
(0.272)\end{array}$ & $\begin{array}{l}0.0546 \\
(0.330)\end{array}$ & $\begin{array}{c}0.411^{* * * *} \\
(0.120)\end{array}$ & $\begin{array}{c}1.417 * * * \\
(0.414)\end{array}$ & $\begin{array}{l}0.42 * * * \\
(0.125)\end{array}$ & $\begin{array}{c}0.473 \\
(0.299)\end{array}$ \\
\hline Constant & $\begin{array}{l}93.13^{* * * *} \\
(32.89)\end{array}$ & $\begin{array}{l}25.97 * * \\
(10.55)\end{array}$ & $\begin{array}{l}35.99 \\
(35.11)\end{array}$ & $\begin{array}{l}14.80^{*} \\
(8.860)\end{array}$ & $\begin{array}{c}83.57 * * * \\
(22.54)\end{array}$ & $\begin{array}{l}76.37 * * \\
(35.01)\end{array}$ & $\begin{array}{c}39.07 * * * \\
(13.62)\end{array}$ & $\begin{array}{l}-25.43 \\
(40.58)\end{array}$ & $\begin{array}{c}53.13 * * * \\
(12.06)\end{array}$ & $\begin{array}{l}-31.39 \\
(48.53)\end{array}$ \\
\hline $\mathrm{N}$ & 243 & 829 & 106 & 602 & 154 & 180 & 460 & 57 & 378 & 37 \\
\hline Year dummy & Yes & Yes & Yes & Yes & Yes & Yes & Yes & Yes & Yes & Yes \\
\hline Chi2 & $0.00^{* * *}$ & $0.00 * * *$ & $0.00 * * *$ & $0.00 * * *$ & $0.00^{* * *}$ & $0.00^{* * *}$ & $0.00^{* * *}$ & $0.00^{* * *}$ & $0.00^{* * *}$ & $0.00^{* * *}$ \\
\hline R2 & 0.641 & 0.381 & 0.514 & 0.559 & 0.548 & 0.546 & 0.42 & 0.79 & 0.436 & 0.939 \\
\hline Variables & $\begin{array}{c}\text { Highly } \\
\text { Democratic }\end{array}$ & $\begin{array}{c}\text { Highly } \\
\text { Autocratic }\end{array}$ & Durable & $\begin{array}{l}\text { Highly } \\
\text { Stable }\end{array}$ & The rest & $\begin{array}{c}\text { Highly } \\
\text { Democratic }\end{array}$ & $\begin{array}{c}\text { Highly } \\
\text { Autocratic }\end{array}$ & Durable & $\begin{array}{l}\text { Highly } \\
\text { Stable }\end{array}$ & The rest \\
\hline Model \# & [1] & [2] & [3] & [4] & [5] & [6] & [7] & [8] & [9] & [10] \\
\hline Logarithm total assets & $\begin{array}{c}-4.563^{* * *} \\
(1.413)\end{array}$ & $\begin{array}{c}-4.207 * * * \\
(1.301)\end{array}$ & $\begin{array}{c}-6.18 * * * \\
(1.628)\end{array}$ & $\begin{array}{c}-1.192^{* *} \\
(0.573)\end{array}$ & $\begin{array}{c}-1.979 * * \\
(0.790)\end{array}$ & $\begin{array}{c}-2.323 \\
(1.547)\end{array}$ & $\begin{array}{c}-4.692 * * * \\
(1.274)\end{array}$ & $\begin{array}{c}-4.846^{* * *} \\
(1.639)\end{array}$ & $\begin{array}{c}-2.943^{* * *} \\
(0.886)\end{array}$ & $\begin{array}{c}-2.515^{* * *} \\
(0.878)\end{array}$ \\
\hline Earning to assets & $\begin{array}{l}0.584^{*} \\
(0.303)\end{array}$ & $\begin{array}{c}0.334^{* *} \\
(0.169)\end{array}$ & $\begin{array}{c}0.485^{* * *} \\
(0.179)\end{array}$ & $\begin{array}{c}2.387 * * * \\
(0.349)\end{array}$ & $\begin{array}{l}0.216^{*} \\
(0.123)\end{array}$ & $\begin{array}{c}0.365 \\
(0.432)\end{array}$ & $\begin{array}{c}0.301 \\
(0.232)\end{array}$ & $\begin{array}{c}0.372 \\
(0.291)\end{array}$ & $\begin{array}{c}1.827 * * * \\
(0.379)\end{array}$ & $\begin{array}{c}0.303 * * \\
(0.150)\end{array}$ \\
\hline Net loans to assets & $\begin{array}{l}-0.032 \\
(0.050)\end{array}$ & $\begin{array}{c}0.001 \\
(0.042)\end{array}$ & $\begin{array}{c}0.045 \\
(0.045)\end{array}$ & $\begin{array}{c}0.0410 \\
(0.0388)\end{array}$ & $\begin{array}{l}-0.0321 \\
(0.0315)\end{array}$ & $\begin{array}{l}-0.107 \\
(0.133)\end{array}$ & $\begin{array}{l}-0.019 \\
(0.099)\end{array}$ & $\begin{array}{c}0.037 \\
(0.096)\end{array}$ & $\begin{array}{c}0.0235 \\
(0.0664)\end{array}$ & $\begin{array}{l}-0.0138 \\
(0.0543)\end{array}$ \\
\hline $\begin{array}{l}\text { Liquid assets to deposits } \\
\text { and short term funding }\end{array}$ & $\begin{array}{c}0.024 * * \\
(0.010)\end{array}$ & $\begin{array}{c}0.042^{* * *} \\
(0.014)\end{array}$ & $\begin{array}{l}0.034^{* *} \\
(0.014)\end{array}$ & $\begin{array}{l}0.130 * * * \\
(0.0307)\end{array}$ & $\begin{array}{c}0.0338^{* * *} \\
(0.0127)\end{array}$ & $\begin{array}{c}0.047 \\
(0.037)\end{array}$ & $\begin{array}{l}0.047 * * \\
(0.023)\end{array}$ & $\begin{array}{c}0.045 \\
(0.028)\end{array}$ & $\begin{array}{l}0.161 * * * \\
(0.0172)\end{array}$ & $\begin{array}{c}0.0471^{* *} \\
(0.0204)\end{array}$ \\
\hline Fixed assets to assets & $\begin{array}{c}0.753 \\
(0.713)\end{array}$ & $\begin{array}{l}-0.179 \\
(0.436)\end{array}$ & $\begin{array}{l}-0.449 \\
(0.342)\end{array}$ & $\begin{array}{c}0.985^{* * *} * \\
(0.269)\end{array}$ & $\begin{array}{c}0.139 \\
(0.297)\end{array}$ & $\begin{array}{c}1.536 \\
(1.105)\end{array}$ & $\begin{array}{c}0.942 \\
(0.863)\end{array}$ & $\begin{array}{c}1.161 \\
(1.062)\end{array}$ & $\begin{array}{c}0.823 \\
(0.584)\end{array}$ & $\begin{array}{c}0.452 \\
(0.486)\end{array}$ \\
\hline Economic development & $\begin{array}{c}0.672 * * * \\
(0.233)\end{array}$ & $\begin{array}{c}0.526 * * * \\
(0.110)\end{array}$ & $\begin{array}{c}0.711^{* * *} \\
(0.158)\end{array}$ & $\begin{array}{c}0.249 * * * \\
(0.0711)\end{array}$ & $\begin{array}{c}0.356 * * * \\
(0.119)\end{array}$ & $\begin{array}{c}0.444 * * * \\
(0.138)\end{array}$ & $\begin{array}{l}-0.064 \\
(0.213)\end{array}$ & $\begin{array}{c}0.442 \\
(0.352)\end{array}$ & $\begin{array}{c}0.401 * * * \\
(0.146)\end{array}$ & $\begin{array}{c}0.447 * * * \\
(0.172)\end{array}$ \\
\hline Constant & $\begin{array}{l}36.06^{*} \\
(20.23)\end{array}$ & $\begin{array}{l}47.61 * * \\
(18.94)\end{array}$ & $\begin{array}{l}60.93 * * \\
(24.06)\end{array}$ & $\begin{array}{c}5.079 \\
(11.82)\end{array}$ & $\begin{array}{l}23.20^{*} \\
(13.33)\end{array}$ & $\begin{array}{c}25.12 \\
(29.65)\end{array}$ & $\begin{array}{c}94.75 * * * \\
(24.41)\end{array}$ & $\begin{array}{l}58.96^{*} \\
(33.60)\end{array}$ & $\begin{array}{c}27.48 \\
(18.30)\end{array}$ & $\begin{array}{l}24.76^{*} \\
(13.35)\end{array}$ \\
\hline $\mathrm{N}$ & 266 & 311 & 246 & 207 & 536 & 189 & 184 & 174 & 105 & 313 \\
\hline Year dummy & Yes & Yes & Yes & Yes & Yes & Yes & Yes & Yes & Yes & Yes \\
\hline Chi2 & $0.00^{* * *}$ & $0.00 * * *$ & $0.00 * * *$ & $0.00 * * *$ & $0.00^{* * *}$ & $0.00^{* * *}$ & $0.00^{* * *}$ & $0.00^{* * *}$ & $0.00^{* * *}$ & $0.00^{* * *}$ \\
\hline R2 & 0.453 & 0.533 & 0.586 & 0.607 & 0.415 & 0.479 & 0.543 & 0.436 & 0.808 & 0.405 \\
\hline
\end{tabular}


Table 11 The determinants of Islamic capital decisions: Listed vs. unlisted banks

Standard errors are clustered at the bank level and are reported in parentheses below their coefficient estimates.

\begin{tabular}{|c|c|c|c|c|c|c|c|c|c|c|}
\hline \multicolumn{6}{|c|}{ Common equity to assets } & \multicolumn{5}{|c|}{ Tier 1 capital to risk weighted assets } \\
\hline Variables & Unlisted & & & & & Unlisted & & & & \\
\hline Model \# & [1] & [2] & [3] & [4] & [5] & [1] & [2] & [3] & [4] & [5] \\
\hline Logarithm total assets & $\begin{array}{c}-2.346 * * * \\
(0.683)\end{array}$ & $\begin{array}{c}-2.333^{* * *} \\
(0.668)\end{array}$ & $\begin{array}{c}-2.441^{* * * *} \\
(0.684)\end{array}$ & $\begin{array}{l}-1.659 * \\
(0.836)\end{array}$ & $\begin{array}{c}-1.732 * * \\
(0.793)\end{array}$ & $\begin{array}{c}-5.918^{* * * *} \\
(1.549)\end{array}$ & $\begin{array}{c}-2.568 * * \\
(0.985)\end{array}$ & $\begin{array}{c}-2.699 * * \\
(1.104)\end{array}$ & $\begin{array}{c}-2.691^{* *} \\
(1.162)\end{array}$ & $\begin{array}{c}-2.977^{* *} \\
(1.162)\end{array}$ \\
\hline Earning to assets & $\begin{array}{c}0.514 \\
(0.321)\end{array}$ & $\begin{array}{c}1.032^{* * *} \\
(0.191)\end{array}$ & $\begin{array}{c}0.993 * * * \\
(0.241)\end{array}$ & $\begin{array}{l}0.82^{* * *} \\
(0.260)\end{array}$ & $\begin{array}{c}0.924 * * * \\
(0.299)\end{array}$ & $\begin{array}{l}0.495^{*} \\
(0.278)\end{array}$ & $\begin{array}{c}1.322^{* * *} \\
(0.414)\end{array}$ & $\begin{array}{c}1.331^{* * * *} \\
(0.420)\end{array}$ & $\begin{array}{c}1.393^{* * * *} \\
(0.427)\end{array}$ & $\begin{array}{c}1.706^{* * *} \\
(0.334)\end{array}$ \\
\hline Net loans to assets & $\begin{array}{c}-0.029 \\
(0.069)\end{array}$ & $\begin{array}{c}0.058 \\
(0.042)\end{array}$ & $\begin{array}{c}0.058 \\
(0.040)\end{array}$ & $\begin{array}{c}0.094^{* *} \\
(0.043)\end{array}$ & $\begin{array}{c}0.102^{* *} \\
(0.047)\end{array}$ & $\begin{array}{l}-0.037 \\
(0.096)\end{array}$ & $\begin{array}{c}0.068 \\
(0.061)\end{array}$ & $\begin{array}{c}0.054 \\
(0.063)\end{array}$ & $\begin{array}{c}0.042 \\
(0.057)\end{array}$ & $\begin{array}{c}0.052 \\
(0.052)\end{array}$ \\
\hline $\begin{array}{l}\text { Liquid assets to deposits and short term } \\
\text { funding }\end{array}$ & $\begin{array}{c}0.094^{* * *} \\
(0.02)\end{array}$ & $\begin{array}{c}0.012 \\
(0.009)\end{array}$ & $\begin{array}{l}0.011 \\
(0.01)\end{array}$ & $\begin{array}{c}0.024^{* *} \\
(0.01)\end{array}$ & $\begin{array}{c}0.024 * * \\
(0.01)\end{array}$ & $\begin{array}{c}0.04 \\
(0.028)\end{array}$ & $\begin{array}{c}0.095 \\
(0.089)\end{array}$ & $\begin{array}{c}0.092 \\
(0.091)\end{array}$ & $\begin{array}{c}0.111 \\
(0.096)\end{array}$ & $\begin{array}{c}0.078 \\
(0.084)\end{array}$ \\
\hline Fixed assets to assets & $\begin{array}{l}0.852^{*} \\
(0.442)\end{array}$ & $\begin{array}{l}0.251 \\
(0.36)\end{array}$ & $\begin{array}{c}0.281 \\
(0.437)\end{array}$ & $\begin{array}{c}0.410 \\
(0.397)\end{array}$ & $\begin{array}{c}0.407 \\
(0.411)\end{array}$ & $\begin{array}{c}0.659 \\
(0.800)\end{array}$ & $\begin{array}{l}1.825^{* *} \\
(0.739)\end{array}$ & $\begin{array}{l}1.724^{* *} \\
(0.727)\end{array}$ & $\begin{array}{l}1.694 * * \\
(0.710)\end{array}$ & $\begin{array}{c}2.016^{* * * *} \\
(0.580)\end{array}$ \\
\hline Economic development & $\begin{array}{l}0.371^{*} \\
(0.213)\end{array}$ & $\begin{array}{c}0.716^{* * *} \\
(0.0969)\end{array}$ & $\begin{array}{c}0.709 * * * \\
(0.101)\end{array}$ & $\begin{array}{c}0.687 * * * \\
(0.108)\end{array}$ & $\begin{array}{c}0.690 * * * \\
(0.107)\end{array}$ & $\begin{array}{c}0.648 \\
(0.411)\end{array}$ & $\begin{array}{c}0.817^{* * *} \\
(0.140)\end{array}$ & $\begin{array}{c}0.820^{* * * *} \\
(0.149)\end{array}$ & $\begin{array}{c}0.787 * * * \\
(0.174)\end{array}$ & $\begin{array}{c}0.805^{* * * *} \\
(0.189)\end{array}$ \\
\hline Market-to-book & & $\begin{array}{l}2.597 * \\
(1.344)\end{array}$ & $\begin{array}{c}1.734 \\
(1.353)\end{array}$ & $\begin{array}{c}2.089 \\
(1.335)\end{array}$ & $\begin{array}{c}1.989 \\
(1.335)\end{array}$ & & $\begin{array}{c}0.820 \\
(1.845)\end{array}$ & $\begin{array}{c}-0.232 \\
(1.865)\end{array}$ & $\begin{array}{c}-0.476 \\
(1.872)\end{array}$ & $\begin{array}{l}-1.166 \\
(1.720)\end{array}$ \\
\hline Dividend per share & & & $\begin{array}{c}0.455 \\
(0.317)\end{array}$ & $\begin{array}{c}0.436 \\
(0.328)\end{array}$ & $\begin{array}{c}0.378 \\
(0.347)\end{array}$ & & & $\begin{array}{c}-0.444 \\
(0.290)\end{array}$ & $\begin{array}{l}-0.477 \\
(0.297)\end{array}$ & $\begin{array}{l}-0.627^{*} \\
(0.327)\end{array}$ \\
\hline Fee income to total operating income & & & & $\begin{array}{c}2.471 \\
(4.314)\end{array}$ & $\begin{array}{c}4.688 \\
(4.290)\end{array}$ & & & & $\begin{array}{l}-2.138 \\
(5.450)\end{array}$ & $\begin{array}{c}8.674 \\
(5.494)\end{array}$ \\
\hline $\begin{array}{l}\text { Non-interest income to total operating } \\
\text { income }\end{array}$ & & & & & $\begin{array}{l}-2.610 \\
(3.026)\end{array}$ & & & & & $\begin{array}{l}-12.70^{*} \\
(6.863)\end{array}$ \\
\hline Constant & $\begin{array}{l}25.82 \\
(16.79)\end{array}$ & $\begin{array}{l}-3.489 \\
(10.33)\end{array}$ & $\begin{array}{c}-0.575 \\
(10.86)\end{array}$ & $\begin{array}{l}-16.75 \\
(10.73)\end{array}$ & $\begin{array}{l}-15.81 \\
(10.17)\end{array}$ & $\begin{array}{l}59.39 * \\
(33.19)\end{array}$ & $\begin{array}{l}-7.260 \\
(13.50)\end{array}$ & $\begin{array}{c}2.071 \\
(15.46)\end{array}$ & $\begin{array}{c}5.343 \\
(14.64)\end{array}$ & $\begin{array}{l}11.95 \\
(11.89)\end{array}$ \\
\hline $\mathrm{N}$ & 476 & 171 & 164 & 159 & 159 & 248 & 145 & 140 & 138 & 138 \\
\hline Country level & No & No & No & No & No & No & No & No & No & No \\
\hline Year dummy & Yes & Yes & No & Yes & Yes & Yes & Yes & Yes & Yes & Yes \\
\hline R2 & 0.4114 & 0.4955 & 0.4795 & 0.4637 & 0.4675 & 0.4604 & 0.5779 & 0.5899 & 0.5857 & 0.6222 \\
\hline
\end{tabular}

* Statistical significance at the $5 \%$ level.

*** Statistical significance at the $1 \%$ level. 
Table 12

Additional analysis: IV approach and other estimation techniques

\begin{tabular}{|c|c|c|c|c|c|c|c|c|}
\hline \multirow{4}{*}{$\begin{array}{l}\text { Variables } \\
\text { Model \# }\end{array}$} & \multicolumn{8}{|c|}{ Panel A. Instrumental variables to address endogeneity concerns } \\
\hline & \multicolumn{4}{|c|}{ Common equity to assets } & \multicolumn{4}{|c|}{ Tier 1 capital to risk weighted assets } \\
\hline & 2SLS & LIML & & GMM & 2SLS & LIML & & GMM \\
\hline & {$[1]$} & {$[2]$} & & [3] & [4] & [5] & & [6] \\
\hline Logarithm total assets & $\begin{array}{c}-1.961 * * * \\
(0.258)\end{array}$ & $\begin{array}{c}-1.96 * * * \\
(0.258)\end{array}$ & & $\begin{array}{c}-1.884^{* * *} \\
(0.252)\end{array}$ & $\begin{array}{c}-3.893 * * * \\
(0.658)\end{array}$ & $\begin{array}{r}-3.901^{* *} \\
(0.662)\end{array}$ & & $\begin{array}{c}-3.917 * * * \\
(0.656)\end{array}$ \\
\hline \multirow[t]{2}{*}{ Earning to assets } & $0.577 * *$ & $0.576^{* *}$ & & $0.597 * *$ & $0.933 * * *$ & $0.935^{* * *}$ & & $0.988^{* * *}$ \\
\hline & $(0.260)$ & $(0.260)$ & & $(0.262)$ & $(0.254)$ & $(0.255)$ & & $(0.253)$ \\
\hline Net loans to assets & $\begin{array}{l}-0.032 \\
(0.026)\end{array}$ & $\begin{array}{l}-0.032 \\
(0.026)\end{array}$ & & $\begin{array}{l}-0.028 \\
(0.026)\end{array}$ & $\begin{array}{c}-0.001 \\
(0.039)\end{array}$ & $\begin{array}{l}-0.001 \\
(0.039)\end{array}$ & & $\begin{array}{c}-0.002 \\
(0.039)\end{array}$ \\
\hline Liquid assets to deposits & $0.095 * * *$ & $0.095^{* * *}$ & & $0.095 * * *$ & $0.055 * * *$ & $0.055^{* * *}$ & & $0.054 * * *$ \\
\hline and short term funding & $(0.013)$ & $(0.013)$ & & $(0.013)$ & $(0.016)$ & $(0.016)$ & & $(0.016)$ \\
\hline \multirow{2}{*}{ Fixed assets to assets } & $0.411^{* *}$ & $0.409 * *$ & & $0.449 * *$ & $1.574^{* * *}$ & $1.576^{* * *}$ & & $1.633^{* * *}$ \\
\hline & $(0.192)$ & $(0.192)$ & & $(0.191)$ & $(0.484)$ & $(0.485)$ & & $(0.482)$ \\
\hline \multirow[t]{2}{*}{ Economic development } & $0.194 * * *$ & $0.193^{* * *}$ & & $0.201 * * *$ & $0.854 * * *$ & $0.858^{* * *}$ & & $0.85^{* * *}$ \\
\hline & $(0.057)$ & $(0.057)$ & & $(0.057)$ & $(0.130)$ & $(0.132)$ & & $(0.129)$ \\
\hline \multirow[t]{2}{*}{ Constant } & $28.12 * * *$ & $28.22 * * *$ & & $26.36 * * *$ & $16.53^{* *}$ & $16.38^{* *}$ & & $17.07 * *$ \\
\hline & (5.469) & $(5.477)$ & & (5.316) & (7.298) & (7.322) & & $(7.250)$ \\
\hline $\mathrm{N}$ & 825 & 825 & & 825 & 471 & 471 & & 471 \\
\hline Year dummy & Yes & Yes & & Yes & Yes & Yes & & Yes \\
\hline Wald chi2 & $0.000^{* * *}$ & $0.000^{* * *}$ & & $0.000 * * *$ & $0.000 * * *$ & $0.000^{* * *}$ & & $0.000^{* * * *}$ \\
\hline R2 & 0.417 & 0.417 & & 0.4178 & 0.453 & 0.452 & & 0.452 \\
\hline F-test/GMM C stat. & $26.52 * * *$ & n.a. & & $25.71 * * *$ & $45.42 * * *$ & n.a. & & 2.047 \\
\hline Sargan/ Hansen's J test & 2.392 & n.a. & & 2.034 & 1.682 & n.a. & & 1.877 \\
\hline \multirow[t]{2}{*}{ Basmann } & 2.341 & 2.341 & & n.a. & 1.877 & 1.616 & & n.a. \\
\hline & \multicolumn{8}{|c|}{ Panel B. Alternative estimation techniques and standard errors } \\
\hline Model \# & $\begin{array}{c}\text { Truncated } \\
{[1]}\end{array}$ & $\begin{array}{c}\text { Quantile } \\
{[2]}\end{array}$ & $\begin{array}{c}\text { White } \\
\text { [3] }\end{array}$ & $\begin{array}{c}\text { Bootstrap } \\
{[4]}\end{array}$ & $\begin{array}{c}\text { Truncated } \\
{[5]}\end{array}$ & $\begin{array}{c}\text { Quantile } \\
\text { [6] }\end{array}$ & $\begin{array}{c}\text { White } \\
\text { [7] }\end{array}$ & $\begin{array}{c}\text { Bootstrap } \\
{[8]}\end{array}$ \\
\hline Logarithm total assets & $\begin{array}{c}-17.38^{* * *} \\
(1.571)\end{array}$ & $\begin{array}{c}-1.008^{* * *} \\
(0.294)\end{array}$ & $\begin{array}{c}-2.334 * * * \\
(0.685)\end{array}$ & $\begin{array}{c}-2.33^{* * *} \\
(0.586)\end{array}$ & $\begin{array}{c}-12.37 * * * \\
(4.300)\end{array}$ & $\begin{array}{c}-2.056^{* * *} \\
(0.543)\end{array}$ & $\begin{array}{c}-3.148 * * * \\
(0.769)\end{array}$ & $\begin{array}{c}-3.148^{* * *} \\
(0.652)\end{array}$ \\
\hline \multirow[t]{2}{*}{ Earning to assets } & $3.648 * * *$ & $1.084 * * *$ & $0.352^{* *}$ & $0.352 * *$ & $2.579 * * *$ & $1.062 * * *$ & $0.454^{* *}$ & $0.454^{* *}$ \\
\hline & $(1.009)$ & $(0.410)$ & $(0.137)$ & $(0.169)$ & $(0.915)$ & $(0.195)$ & $(0.178)$ & $(0.193)$ \\
\hline Net loans to assets & $\begin{array}{c}0.166 \\
(0.122)\end{array}$ & $\begin{array}{c}0.0255 \\
(0.0283)\end{array}$ & $\begin{array}{c}-0.00809 \\
(0.0299)\end{array}$ & $\begin{array}{l}-0.008 \\
(0.025)\end{array}$ & $\begin{array}{l}-0.122 \\
(0.143)\end{array}$ & $\begin{array}{c}-0.0371 \\
(0.0304)\end{array}$ & $\begin{array}{l}-0.0340 \\
(0.0532)\end{array}$ & $\begin{array}{c}-0.0340 \\
(0.0422)\end{array}$ \\
\hline \multirow{4}{*}{$\begin{array}{l}\text { Liquid assets to deposits } \\
\text { and short term funding } \\
\text { Fixed assets to assets }\end{array}$} & $0.231^{* * *}$ & $0.120 * * *$ & $0.0404 * * *$ & $0.04^{* * *}$ & 0.054 & $0.0531^{* * *}$ & $0.0363^{* *}$ & $0.0363 * *$ \\
\hline & $(0.049)$ & $(0.0140)$ & $(0.0132)$ & $(0.013)$ & $(0.033)$ & $(0.0157)$ & $(0.0160)$ & $(0.0164)$ \\
\hline & $3.512^{* * *}$ & $0.960^{* *}$ & 0.263 & 0.263 & $5.045^{* * *}$ & $1.848 * *$ & 0.528 & 0.528 \\
\hline & $(0.714)$ & $(0.481)$ & $(0.230)$ & $(0.239)$ & $(1.891)$ & $(0.802)$ & $(0.551)$ & $(0.674)$ \\
\hline \multirow[t]{2}{*}{ Economic development } & $3.015 * * *$ & $0.297 * * *$ & $0.293 * * *$ & $0.293 * * *$ & $1.733 * * *$ & $0.533^{* * *}$ & $0.542 * * *$ & $0.542 * * *$ \\
\hline & $(0.281)$ & $(0.0762)$ & $(0.111)$ & $(0.069)$ & $(0.631)$ & $(0.110)$ & $(0.147)$ & $(0.104)$ \\
\hline \multirow[t]{2}{*}{ Constant } & -24.99 & -2.625 & $29.73 * * *$ & $29.73 * * *$ & 56.89 & 6.557 & $30.17 * *$ & $30.17 * *$ \\
\hline & (27.43) & $(6.266)$ & (11.17) & $(8.892)$ & (42.19) & (6.817) & $(14.01)$ & $(12.60)$ \\
\hline $\mathrm{N}$ & 807 & 862 & 862 & 862 & 433 & 472 & 472 & 472 \\
\hline Year dummy & Yes & Yes & Yes & Yes & Yes & Yes & Yes & Yes \\
\hline Chi2 & $0.000 * * *$ & n.a. & $0.000 * * *$ & $0.000 * * *$ & $0.000^{* * *}$ & n.a. & $0.000^{* * *}$ & $0.000 * * *$ \\
\hline R2 & n.a. & 0.388 & 0.388 & 0.388 & n.a. & 0.43 & 0.436 & 0.436 \\
\hline
\end{tabular}

Sargan test is reported for 2SLS and LIML models while the Hansen J test is reported for the GMM model. Standard errors are clustered at the bank level and are reported in parentheses below their coefficient estimates. In panel B, we show results from heteroscedasticity-consistent standard errors (Models

3 and 7) and standard errors based on bootstrapping techniques (100 random resamples) (Models 4 and 8).

* Statistical significance at the $10 \%$ level.

** Statistical significance at the $5 \%$ level.

*** Statistical significance at the $1 \%$ level. 


\section{Figures}

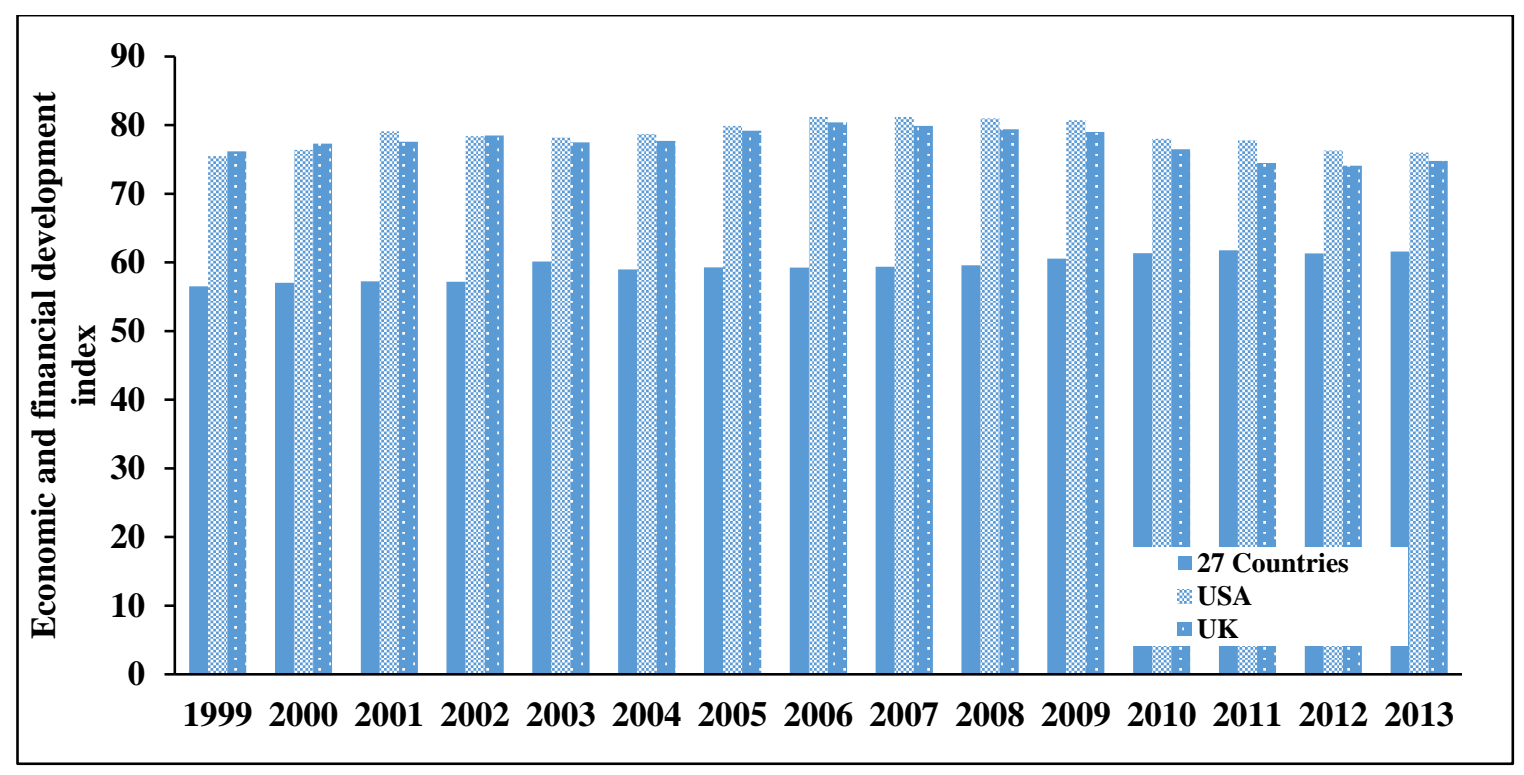

Fig. 1.A Economic and financial development index for a sample of more than 100 Islamic banks in 28 countries. Panel A plots the average of the economic and the financial development index for the period between 1999 and 2013. The graph compares economic and financial development between USA, UK and the rest of countries where Islamic banks operate.

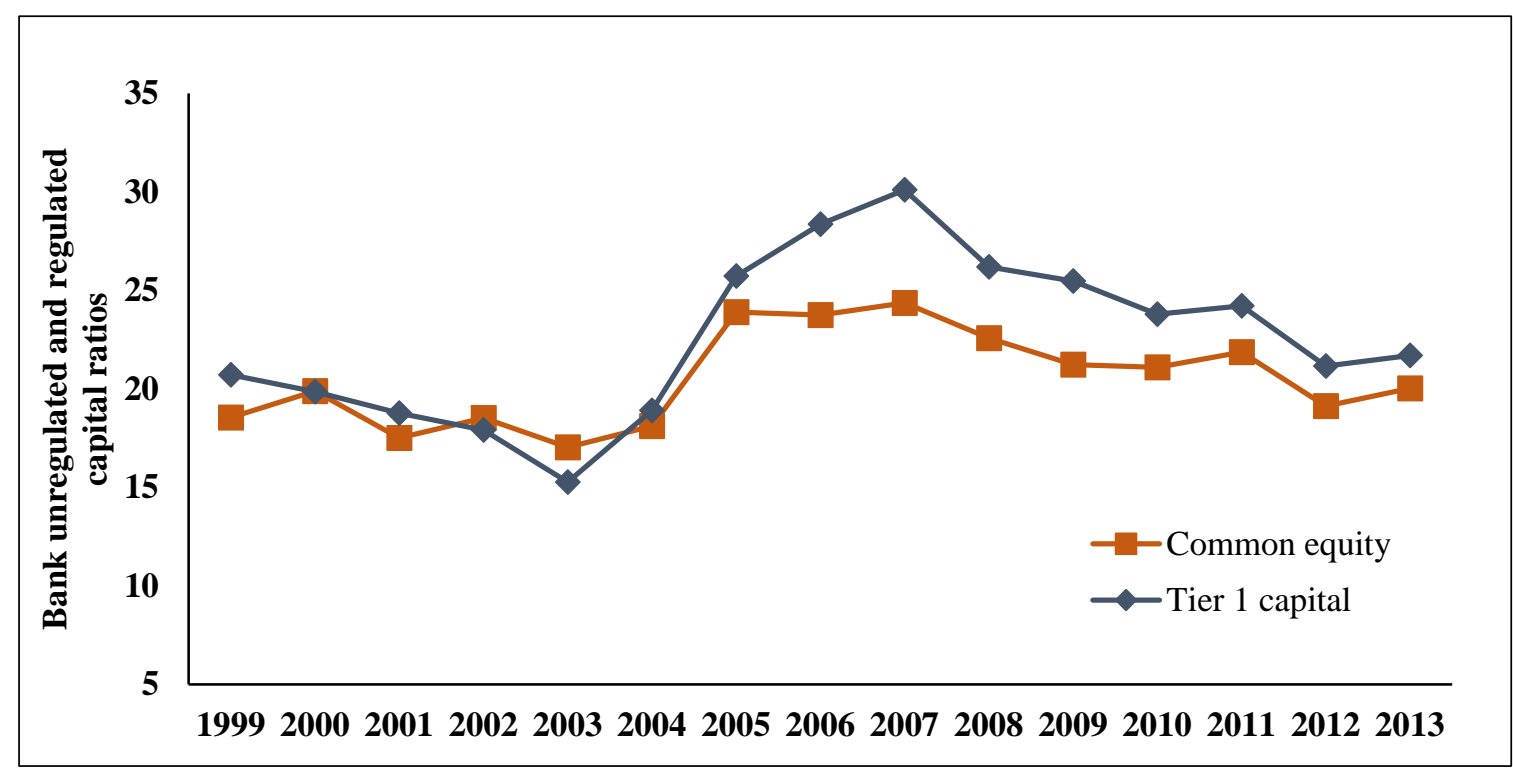

Fig. 1.B Bank capital ratios for a sample of more than 100 Islamic banks in 28 countries. The graph plots the average of the capital ratios defined as common equity to total assets (unregulated capital) and Tier 1 capital to risk-weighted assets (regulated capital) for the period between 1999 and 2013. 